\title{
PROTEOME ANALYSIS OF MALE GAMETOPHYTE DEVELOPMENT IN RICE ANTHERS
}

\author{
A thesis submitted for the degree of \\ Doctor of Philosophy \\ at

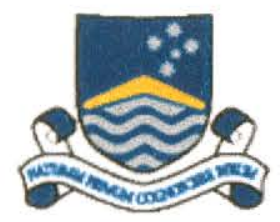 \\ THE AUSTRALIAN \\ NATIONAL UNIVERSITY
}

By

Tursun Kerim

Research School of Biological Sciences

November 2003 


\section{CHAPTER 5 IDENTIFICATION AND \\ CHARACTERIZATION OF RICE HOMOLOGUES OF GRASS GROUP II POLLEN ALLERGENS}

[The research presented in this chapter has been published : Kerim, T., Imin, N., Weinman, J. J. and Rolfe, B. G (2003). Proteome analysis reveals developmentally expressed rice homologues of grass group II pollen allergens, Functional Plant biology, 30 (8): 843-852.]

\section{SUMMARY}

Three isoallergens of Ory s 2, homologues of grass group II pollen allergens, were identified from rice and characterised by proteome and immunochemical analyses. The $N$-terminal amino acid sequence profiles of three proteins on a 2-Dimensional electrophoresis (2-DE) gel of rice pollen proteins matched $100 \%$ to the protein sequences encoded by three rice ESTs. The deduced protein sequences from these ESTs share sequence identities of $41-43 \%$ with the protein sequences of the group II pollen allergens of different grasses, and sequence identity of $39 \%$ with the C-terminal portion of rice group I pollen allergens. Signal peptide sequences, which are similar to the leader peptides of other major pollen allergens, are also present in the deduced amino acid sequences. Polyclonal antibodies, produced in rabbits using Ory s 2 proteins purified by 2-DE, were used to investigate the developmental stage and tissue specific expression of Ory s 2 by immunochemical analyses. The results of immunochemical experiments demonstrated the late stage-specific expression patterns of Ory $s$ proteins, indicating the possible involvement of these proteins during the fertilization process. The Ory s 2 proteins do not cross-react with group II pollen allergens from some other common grasses.

\subsection{INTRODUCTION}

The grass family comprises about 9,000 species, and they are the most important group of plants both in ecological and economical terms. At the same time, they are also a main cause of allergic disease worldwide. Hayfever and seasonal allergic asthma resulting from the grass pollen allergies can affect a substantial proportion (20-25\%) of the human population living in temperate regions (Wuthrich 1989; Griffith et al. 1991;). 
Several groups of allergens from different grass pollens have already been isolated and characterised (for review see Andersson and Lidholm 2003; Ticha et al. 2002). The allergenic properties of most of the identified grass pollen allergens are well studied. However, the precise biological functions of most of the grass pollen allergens are largely unknown (Andersson and Lidholm 2003).

One group of well-characterised grass pollen allergens is the group II allergens, which are a group of acidic small proteins ( $\mathrm{pH}$ 5.0-5.3) with a molecular weight of 10 $12 \mathrm{kDa}$ (Freidhoff et al. 1986; Ansari et al. 1989b). Lol p II from the perennial rye grass is one of the extensively investigated group II pollen allergens, towards which $45 \%$ of grass pollen allergic patients are sensitive (Freidhoff, Ehrlich-Kautzky et al. 1986; Ansari et al. 1987; Ansari et al. 1989a;). Group II allergens have also been identified and characterised from orchard grass (Roberts et al. 1993a), timothy grass (Dolecek et al. 1993), Bermuda grass, Kentucky blue grass and wheat (NCBI accession numbers are CAA10346, CAA10348 and CAA10349, respectively. Submitted by Sturaro et al).

Rice (Oryza sativa), a member of the grass subfamily Bambusoideae, is cultivated as a major cereal crop in most populated Asian regions. Airborne rice pollens originating from rice fields can be a trigger of seasonal hayfever for the rice farmers and people living near rice growing regions because protein extracts of rice pollen have shown cross-allergenicity with other grasses (Kimura et al. 1969; Smith et al. 1994a). It also has been reported that there is a significant correlation between airborne rice pollen counts and asthma episodes in children during the flowering season of rice plants in Japan (Matsumura et al. 1969). In Taiwan, skin prick tests of asthmatic patients using rice pollen extracts showed that $9.3 \%$ of the asthmatic patients had a positive reaction. In addition, immunoblotting studies using positive serum from asthma patients revealed three major allergens with molecular weights of 16,26 and $32 \mathrm{kDa}$, respectively (Tsai et al. 1990). Ory s 1, a gene coding for the group I allergen of rice pollen, has been cloned and characterised by molecular biological and immunochemical methods (Xu, Theerakulpisut et al. 1995a; Xu et al. 1999). Western blot analysis demonstrated that the Ory s 1 encodes a protein which shares high level of cross allergenicity with other grasses. These studies suggested that rice pollen allergens could be major triggers of hay fever and seasonal asthma. However, the rice pollen allergens were poorly characterised compared to their counterparts in other grasses. One reason for this situation could be the low prevalence of rice pollen as an aeroallergen in metropolitan 
areas. Although group II pollen allergens have been identified from several common grasses, so far there has been no report about isolation and characterisation of group II pollen allergens from rice.

As presented in the results of Chapter 4, the $N$-terminal amino acid sequences of the two differentially displayed rice anther protein spots were shown to match three TC sequences in the database. The deduced protein sequences of the TC sequences were shown to share some level of sequence homology with grass group II pollen allergens. Because of the stage specific regulation and the high abundance levels in the late pollen developmental stages, these proteins were chosen for further characterization using immunochemical and computer analysis tools. In this chapter, the tissue and stagespecific expression of rice group II pollen allergens, and their cross-antigenicity with other grasses were studied using polyclonal antibodies raised against the gel-purified proteins. At the same time, an attempt was made to study the interaction of the group II pollen allergens with rice pollen and style proteins using immunoprecipitation in order to identify the protein interaction networks, in which the group II allergens are involved. The main aim of this chapter was to further characterise the spatial and temporal expression of rice group II pollen allergens, and to examine their use as potential protein markers of specific pollen developmental stages.

\subsection{MATERIALS AND METHODS}

\subsubsection{Plant material}

The Australian rice cultivar, Doongara, was grown in a glass house as described in Chapter 2. Mature pollen grains were isolated from fresh heading stage panicles according to Schrauwen et al (1990). with some modifications. In order to obtain a near synchronous pollen population, only the top three primary branches were used in the experiments. The panicles were homogenized for $1 \mathrm{~min}$ in iced $0.3 \mathrm{M}$ mannitol using an electric blender (Quickie-Super-7, Matsushita Elec. Ltd, Osaka, Japan). The suspension was filtered through a nylon sieve $(70 \mathrm{~mm})$ and pollen grains were pelleted by centrifugation at low speed $(250 \mathrm{~g}, 1 \mathrm{~min})$. The pellet was washed twice in iced $0.3 \mathrm{M}$ mannitol. After the final wash, the isolated pollen grains were kept at $-80{ }^{\circ} \mathrm{C}$ until use. The anthers, palea, lemma, and stigmas were collected from the rice plants at heading stage by manual dissection of the spikelets using a pair of forceps and a scalpel. The top 
flag leaves were also collected from the same plants for immunoblot analysis. All the plant materials were kept at $-80{ }^{\circ} \mathrm{C}$ until use. The pollens of Bermuda grass (Cynodon dactylon), maize (Zea mays), Kentucky blue grass (Poe pratensis), rye grass (Lolium perenne), timothy grass (Phleum pratense) and wheat (Triticum aestivum) were obtained from Greer Laboratories (NC, USA.)

\subsubsection{Two-dimensional gel electrophoresis}

The protein extraction from rice pollens and the 2-DE analysis was carried out as described in Chapter 2.

\subsubsection{Computer analysis}

The conserved domain search of the predicted protein sequence was done using the Pfam 7.6 database available at http://pfam.wustl.edu/ and ScanProsite (Gattiker et al. 2002) available at http://www.expasy.ch/tools/scanprosite/. Multiple sequence alignments were performed using the ClustalX program (Thompson et al. 1997). The phylogenetic tree was constructed based on the distance matrix between sequence pairs using the MegAlign program of the DNASTAR software package (DNASTAR, Inc, Madison, USA)

\subsubsection{Antibody production}

Polyclonal antibody production using 2-DE purified proteins was done as previously described (Drenckhahn et al. 1993) with some modifications. Briefly, the pH 5 to 6 portions of multiple isoelectrically focused $18 \mathrm{~cm}$ IPG strips (pH 4 to 7), which contained the proteins of interest, were separated in the second dimension as described in section 2.3 of Chapter 2. Then, the proteins were electroblotted onto nitrocellulose membranes (Amershem Biosciences, Uppsala, Sweden), and the transferred protein spots were visualised by staining the membranes in $0.1 \%(\mathrm{w} / \mathrm{v})$ Ponceau $\mathrm{S}$ in $1 \%(\mathrm{v} / \mathrm{v})$ acetic acid for $1 \mathrm{~min}$. The membrane bound protein spots were excised from the membranes, destained in deionised water and homogenised in liquid nitrogen until powdered. The homogenised membrane powder containing approximately $50 \mu \mathrm{g}$ of gel purified Ory s 2 proteins was suspended in $2 \mathrm{~mL}$ of PBS ( $\mathrm{pH} 7.6)$ and injected subcutaneously into New Zealand white rabbits. Two booster injections were administrated three and six weeks after the first injection. Blood was withdrawn from an 
ear vein every two weeks and the antibody titre was checked by Western blot analysis. Prior to immunisation, pre-immune serum was taken as a control.

\subsubsection{Immunoblotting}

To study the tissue and stage specific expression of Ory s 2-A and Ory s 2-B/C, the plant materials including rice anthers collected at different stages, mature pollen, leaf, stigma, shoot, root and palea-lemma were homogenised in a liquid nitrogen-cooled mortar and pestle before adding SDS sample buffer (63 mM Tris-HCl, 10\% Glycerol, $2 \% \mathrm{SDS}, \mathrm{pH}$ 6.8). The extracts were boiled, centrifuged (12000 x g) to remove insoluble materials, and the supernatant was collected. The protein concentration of the diluted supernatant was determined by Bradford dye-binding assay (Bio-Rad, Hercules, CA). The samples containing $60 \mu \mathrm{g}$ of total proteins were fractionated using Novex precast 10-20\% Tricine gels (Invitrogen, Carlsbad, CA). For 2-DE immunoblot of pollen proteins, the sample was fractionated using $11 \mathrm{~cm} \mathrm{IPG} \mathrm{strips} \mathrm{(pH} 4$ to 7) and 1214\% ExcelGel-SDS gels. The proteins separated by SDS-PAGE and 2-DE were transferred onto PVDF membrane (Bio-Rad, Hercules, CA) using the same method as described in Chapter 2. After the protein transfer, non-specific binding sites on the membranes were blocked by incubating the membranes in $7 \%$ skim milk powder in TBS-T (20 mM Tris-HCl, pH 7.6, $150 \mathrm{mM} \mathrm{NaCl,} \mathrm{0.05 \%} \mathrm{(v/v)} \mathrm{Tween} \mathrm{20)} \mathrm{overnight} \mathrm{at}$ $4^{\circ} \mathrm{C}$. The blots were incubated for $60 \mathrm{~min}$ at room temperature with antiserum $(1: 3000$ dilution in TBS-T) raised against Ory s 2-A and Ory s 2-B/C, and were developed with an ECL-Plus western blot detection kit (Amersham Biosciences, Uppsala, Sweden) according to the manufacturer's instructions. Horseradish peroxidase conjugated antirabbit IgG (Amersham Biosciences, Uppsala, Sweden) was used as a secondary antibody.

\subsubsection{Immunolocalisation}

Rice anthers from heading stage were briefly degassed in a fixing solution containing 4\% (v/v) formaldehyde in phosphate buffer (0.1 M NaPO4, $\mathrm{pH} 7.2)$ and incubated at room temperature for two hours. After three washes with phosphate buffer, the material was dehydrated through a graded ethanol series $(60 \%, 70 \%, 90 \%$ and $100 \%, \mathrm{v} / \mathrm{v})$. Then, the material was infiltrated and embedded in hydroxyethyl methacrylate resin in ultra thin PCR tubes using a Leica Historesin embedding kit 
(Leica Instruments, Wetzlar, Germany) according to the manufacturer's instructions. Semi-thin sections (2-4 mm) were cut with a glass knife on a Reichert-Jung ultramicrotome (Leica Instruments, Germany) and were mounted on poly-L-lysinecoated glass slides (Sigma, St.Louis, MO). The immunological detection was carried out as described before (Cho and Kende 1998) with some modifications. Nonspecific binding sites of the sections were blocked by incubating the sections in $2 \%(\mathrm{w} / \mathrm{v})$ cold fish gelatine in TBS-T for $30 \mathrm{~min}$ at room temperature. The sections were incubated with anti- Ory s 2-B/C antibody diluted to $1: 50$ with TBS-T containing $0.1 \%(\mathrm{w} / \mathrm{v})$ bovine serum albumin overnight at $4^{\circ} \mathrm{C}$ in a moist chamber. After washing three times with TBS-T- BSA solution for $30 \mathrm{~min}$, the sections were incubated with anti-rabbit IgGalkaline phosphatase conjugate (1: 100 dilution, Boehringer Mannheim, Mannheim, Germany) in a TBS-T-BSA solution for $60 \mathrm{~min}$ in a moist chamber at room temperature. The sections were washed three times with TBS-T- BSA solution for 45 min and the colour reaction was performed using NBT/BCIP stock solution (Boehringer Mannheim) according to the manufacturer's instructions. Levamisole was added to the substrate at a final concentration of $1 \mathrm{mM}$ to block the endogenous alkaline phosphatase activity of the anther sections. Control sections were treated identically except that preimmune rabbit serum was substituted for Ory s $2-\mathrm{B} / \mathrm{C}$ antibody in the primary antibody incubation step. The slides were mounted with Permount (Fisher Scientific) and observed under Nikon Optiphot light microscope. Photographs were taken on Fujichrome 400 colour slide film using a Nikon FX-35 A camera.

\subsubsection{Immunoprecipitation}

Pooled plant material (200 mg of anthers and anthers plus style) was ground in a liquid nitrogen cooled mortar and pestle for $10 \mathrm{~min}$ and solubilised in $1 \mathrm{ml}$ of protein extraction buffer (50mM Tris- $\mathrm{HCl} \mathrm{pH}$ 7.6, $1 \mathrm{mM}$ EDTA, 1mM DTT, 1x Protease inhibitor cocktail) on ice. The homogenate was centrifuged at $10000 \mathrm{~g}$ for $10 \mathrm{~min}$ at 4 ${ }^{\circ} \mathrm{C}$ and the supernatant was saved. The protein concentration of the supernatant was measured using Bradford assay. For each sample, $1 \mathrm{mg}(250 \mu 1$ in volume) of protein extract, $50 \mu \mathrm{l}$ of anti Ory s-2 B/C antibody and $200 \mu 1$ of immunoprecipitation buffer (50mM Tris- $\mathrm{HCl} \mathrm{pH} 7.6,100 \mathrm{mM} \mathrm{NaCl}, 0.5 \%$ (v/v) Nonidet-40, 1mM DTT, 1x Protease inhibitor cocktail) were mixed on ice. The mixture was incubated for 2 hours at $4^{\circ} \mathrm{C}$ on a rotating wheel. In the meantime, the protein A-agarose bead conjugate (Sigma, 
St.Louis, MO) was pre-equilibrated by washing twice with immunoprecipitation buffer and suspended with twice the volume of immunoprecipitation buffer to make $50 \%$ protein A-agarose slurry. An aliquot of this slurry $(100 \mu 1)$ was added to the reaction mix on ice, and the reaction mixture was incubated for further 30 min at $4^{\circ} \mathrm{C}$ on a rotating wheel. The beads were collected by centrifugation at $3000 \mathrm{xg}$ for $2 \mathrm{~min}$ at $4^{\circ} \mathrm{C}$, and washed 3 times with the immunoprecipitation buffer to exclude the unbound proteins. Proteins were eluted from the beads by boiling for $1 \mathrm{~min}$ in $50 \mu 1$ of SDS sample buffer (63 mM Tris-HCl, pH 6.8, 10\% Glycerol, 2\% SDS and 1mM DTT) and separated using Novex precast $10-20 \%$ Tricine gels. The proteins were visualized by colloidal coomassie staining.

\subsection{RESULTS}

\subsubsection{2-DE analysis of pollen proteins}

A proteome map of rice pollens (Figure 5.1), which were isolated from the heading stage panicles, was established by using exactly the same experimental conditions that were used for establishing the anther proteome maps (Chapter 4). The pollen proteome map was then compared to the anther proteome map at the heading stage (Figure 4.6, Chapter 4) to see if the protein spots t1-76 and t1-17 were anther or pollen specific. As shown in Figure 5.1, the protein spots t1-17 and t1-76 were present at the same gel locations where they were present on the anther proteome map at the heading stage (Figure 4.6, Chapter 4). Comparison of the spot volume showed that the volume of 11 76 and $\mathrm{t} 1-17$ on both proteome maps did not change significantly (less than $10 \%$ ), indicating the pollen-specific expression of these proteins.

\subsubsection{Identification of Ory s 2 isoforms by $\mathbf{N}$-terminal sequencing and database searching}

As presented in Chapter 4, the protein spots t1-17 and t1-76 were subjected to $N$ terminal microsequencing analysis. Unequivocal sequence data of 15 amino acid residues was obtained for protein spot t1-76 by $N$-terminal sequencing (Table 5.1). Clear sequence data was obtained for the first 15 amino acid residues for spot t1-17. However, a polymorphism was observed at residue 14 with serine and threonine both being detected in a 0.5 to 0.5 ratio. Figure 5.2 shows the chromatogram of the residue 14 obtained from the N-terminal sequencing of spot t1-17. Based on this data we 
concluded that two distinct proteins with a very similar molecular weight and $\mathrm{p} / \mathrm{s}$ are present at the position of protein spot $\mathrm{t} 1-17$. The separation of the anther proteins using $24 \mathrm{~cm}$ IPG strips also revealed the presence of two protein spots on the location of the spot t1-17 (data not shown). Therefore, two sets of $\mathrm{N}$-terminal amino acid sequences as shown in Table 1 were used for the sequence homology searching for spot t1-17.

FASTA searches of the SWISS-PROT non-redundant protein database using these three sets of experimental $N$-terminal amino acid sequences did not yield any significant matches. BLAST searches of the GenBank protein database for short exact matches revealed that the two N-terminal sequences derived from spot $\mathrm{t} 1-17$ exhibited $100 \%$ sequence identities in 15 amino acid to two hypothetical rice proteins, OSJNBa0050F15.10 (CAD40510) and OSJNBa0050F15.9 (CAD40509), predicted from genomic sequencing (Table 1). Further tBLASTn searching of TIGR rice gene index revealed that each of the three $N$-terminal sequences displayed $100 \%$ identity over 15 amino acid residues to the ORF products of three TC sequences (Table 5.1). Each of the matching ORFs encodes for a polypeptide of 117 amino acids with a molecular weight of about $12 \mathrm{kDa}$. SignalP analysis predicted 23 amino acid long signal peptide sequences in all three deduced protein sequences (Figure 5.3). Furthermore, the cleavage sites of the signal peptides are predicted to be located immediately before the start of the experimentally determined $N$-terminal sequences. The calculated molecular weights and $\mathrm{p} I \mathrm{~s}$ of the deduced mature proteins are in close agreement with those experimentally observed on 2-DE gels. The homology searching of the NCBI protein database using the translated protein sequences revealed that all three sequences share some degree of sequence identities with the group II pollen allergens from various grasses. Therefore, they were designated as Ory s 2-A (t1-76) and Ory s 2-B/C (t1-17).

\subsubsection{Sequence analysis of the matching ORFs}

Alignment of the deduced protein sequences using the ClustalX program showed that these three sequences share $86.3 \%$ (between Ory s 2 -A and Ory s $2-\mathrm{C}$ ), $90.6 \%$ (between Ory s 2-A and Ory s 2-B), and 93.2\% (between Ory s 2-B and Ory s 2-C) amino acid sequence identities with each other (Figure 5.3). The results of conserved domain searching show that all three predicted protein sequences contain a conserved pollen allergen domain (PFAM accession PF01357), which matches to amino acid residues that starts from 26 to 102 in the deduced protein sequences. They also contain 
Figure 5.1. 2-DE map of proteins extracted from the mature pollen of rice cultivar Doongara. For the first dimension, $1 \mathrm{mg}$ of extracted pollen proteins was loaded on an IPG strip (linear $\mathrm{pH} 4-7,18 \mathrm{~cm}$ ). For the second dimension, a 12-14\% SDS-PAGE gel was used. Proteins were visualised by colloidal Coomassie staining. The molecular weight markers are denoted on the left and $\mathrm{p} I$ is indicated at the bottom. The protein spots t1-17 and t1-76 were subjected to N-terminal micro sequencing analysis and the protein spots t1-29 and t1-31 were identified as isoforms of rice group I pollen allergens ( $\beta$-expansins) in Chapter 4. 


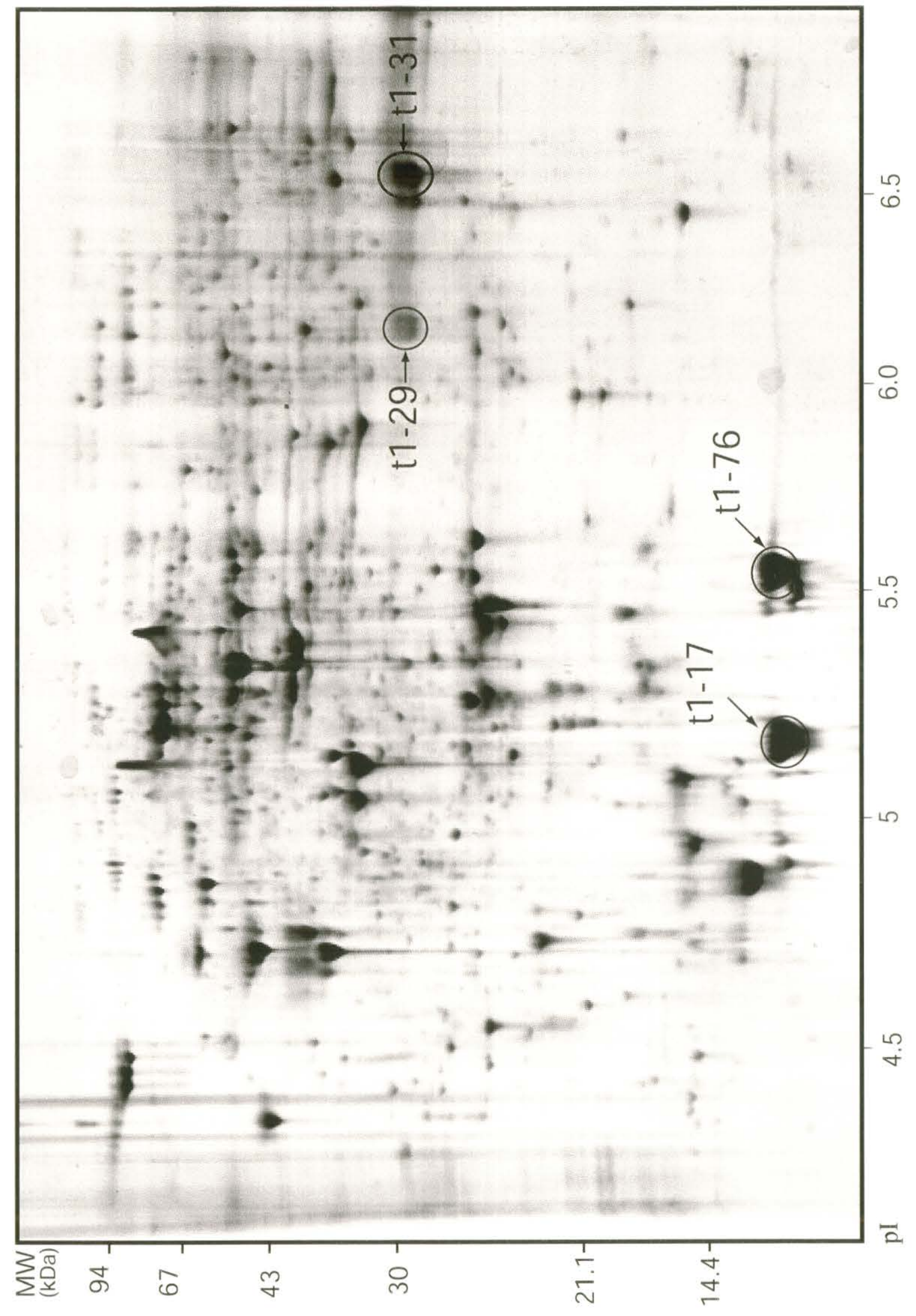





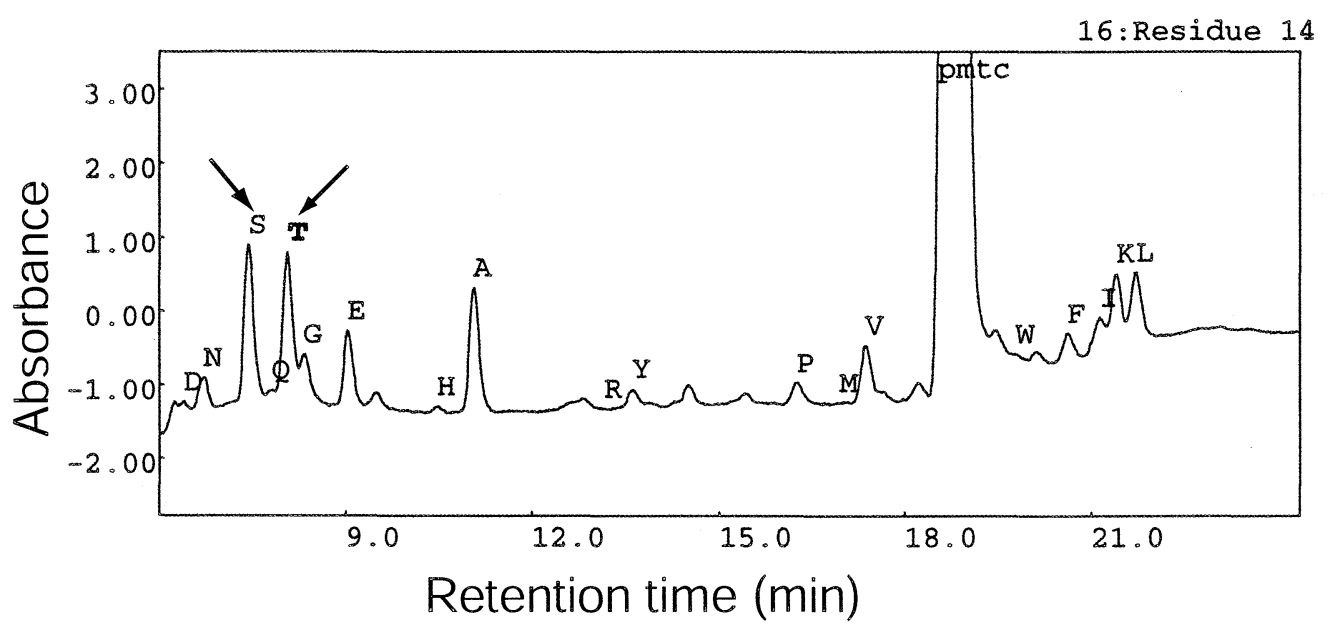

Figure 5.2. Chromatogram of the residue 14 obtained from the $\mathrm{N}$-terminal micro sequencing of spot $\mathrm{t} 1-17$. The single letter amino acid abbreviations above the peaks indicated by arrows are corresponding to two amino acids, Serine and Threonine, obtained for residue 14 of spot $t 1-17$. 
Table 5.1. Proteins analysed by $N$-terminal microsequencing and database searching

\begin{tabular}{|c|c|c|c|c|c|c|c|}
\hline Spot I.D. & $M r /\left.p\right|^{a)}$ & $N$-terminal Sequence & $\begin{array}{c}\text { Homology } \\
\text { (\% identity) }\end{array}$ & $\begin{array}{c}\text { NCBI } \\
\text { accession }\end{array}$ & $M W / p I^{b)}$ & $\begin{array}{c}\text { Signal } \\
\text { peptide }\end{array}$ & TIGR accession \\
\hline \multirow[t]{2}{*}{$\mathrm{t} 1-76$} & $11 / 5.6$ & TEVTFKVGEGSSGKS & $100 \%$ & & $10.0 / 5.45$ & Yes & TC114263 \\
\hline & & TELTFKVAEGSSASS & $100 \%$ & CAD40510 & $10.1 / 5.12$ & Yes & TC125017 \\
\hline \multirow[t]{2}{*}{$\mathrm{t} 1-17$} & $11 / 5.2$ & & & & & & \\
\hline & & TELTFKVAEGSSATS & $100 \%$ & CAD40509 & $10.1 / 5.13$ & Yes & TC129660 \\
\hline
\end{tabular}

a) The observed molecular mass and pl of the protein spots.

b) The predicted molecular mass and isoelectric point of the matched peptides calculated from the ORFs after excluding the predicted signal peptide sequences. 


Figure 5.3. Multiple alignment of the deduced amino acid sequences of three isoforms of Ory s 2 protein. The deduced amino acid sequences of Ory s 2-A (TC114263), Ory s 2-B (TC125017) and Ory s 2-C (TC129660) are aligned using ClustalX program (Thompson). The "*" symbol indicates that the residues in that column are identical in all sequences in the alignment and the ":" and "." indicate that the residues in that column are conserved and semi-conserved, respectively. The experimentally determined $\mathrm{N}$-terminal sequences of Ory s 2 proteins are underlined in red. The blue bar on the top of the columns shows the location of the pollen allergen domain (PFAM accession PF01357) in the alignment. 

an expansin cellulose-binding domain (EXPANSIN_CBD, PROSITE accession PS50843), which matches to amino acid residues 47 to 113 . Both of the domains are the characteristic of group I and group II pollen allergens.

Figure 5.4 demonstrates the alignment of the deduced protein sequences with amino acid sequences of known group II pollen allergens in the database. The Ory s 2 isoforms share comparable amino acid sequence identities (41.7\% to $43.5 \%)$ with group II pollen allergen proteins of orchard grass, Bermuda grass, timothy grass, wheat, velvet grass and Kentucky blue grass. Phylogenetic analysis, which was based on the multiple sequence alignment, yielded a phylogenetic tree as shown in Figure 5.5. On this phylogenetic tree, the isoforms of Ory s 2 form a distinct subgroup, well separated from the other group II pollen allergens. Sequence alignment analysis also indicated 39\%, $41 \%$ and $38 \%$ sequence identities between the deduced protein sequences of Ory s $2-\mathrm{A}$, Ory s 2-B and Ory 2-C, and the C-terminal portion (starts from amino acid residue 168 to 267 ) of rice group I pollen allergen (Ory s 1), respectively (sequence alignment not shown).

\subsubsection{Immunoblot analysis}

Immunological approaches were employed to see if there was any significant immunological cross-reactivity among the two identified protein spots. Western immunoblot analyses of 2-DE separated pollen proteins (in $\mathrm{pH}$ range of 4 to 7 ) were carried out using the polyclonal antibodies produced against the protein spots Ory s 2-A and Ory s 2-B/C. As expected, the Ory s 2-A antibody detected both protein spots t1-76 and t1-17 (Figure 5.6). However, the Ory s 2-A antibody also cross-reacted to a neighbouring low molecular weight protein spot which was located just below the t1-76, indicating the contamination of the t1-76 protein material used for the injection. A very low detection signal was also present in the gel region corresponding to the rice group I pollen allergens ( $\beta$-expansins). The antibody produced against Ory s $2-\mathrm{B} / \mathrm{C}$ detected both protein spots t1-17 and t1-76, but it did not cross-react with the low molecular weight protein next to t1-76 (Figure 5.7). The control experiments using the preimmune serum did not detect the same spots in the replica blot. The Ory s $2-B / C$ antibody was used for the subsequent immunoblot and tissue localisation experiments. 


\subsubsection{Stage- and tissue-specific expression of Ory s 2}

Expressions of Ory s 2 during different pollen developmental stages and in different floral tissues were studied by Western blot immuno-detection analysis. Western blots of rice proteins extracted from rice anthers at four different developmental stages and from different parts of the rice plant, were probed with the anti Ory s 2-B/C polyclonal antibody (Figure 5.8). The results showed that Ory s $2-\mathrm{B} / \mathrm{C}$ was not detected in anthers at the uninucleate microspore stage. Reactivity was first detected at a low level in anthers of early binucleate microspore stage and the expression gradually increased to a high level in anthers at the mature pollen stage. A similar level of expression was observed in anther samples of mature pollen stage and pollen that was isolated from the panicle of the same stage. The same immunoblot analysis also revealed that the Orys 2$\mathrm{B} / \mathrm{C}$ is only expressed in mature pollen and late stage anther but not in any other part of inflorescence, leaves, shoots or roots of rice.

\subsubsection{Cross-reactivity of Ory s 2 to other grasses}

The alignment of deduced amino acid sequences of Ory s 2 to group II pollen allergens of other grasses indicated that they share considerable sequence identity. The anti Ory s 2-B/C polyclonal antibody was used to investigate whether there was any significant immunological cross-reactivity between Ory s 2 and group II pollen allergens of other grasses. The Western immunoblot results showed that the polyclonal antibody did not bind to any protein components, within molecular weight range of 10$12 \mathrm{kDa}$ (group II allergens), in protein extracts of six common grasses (Figure 5.9). However, it bound to a band with a molecular weight of approximately $32 \mathrm{kDa}$ in maize pollen extracts. Although there is a reasonably high level of sequence similarity between Ory s 2 and group II pollen allergens from other grasses as demonstrated by our sequence alignment analysis, no cross-reactivity of Ory s 2 to these allergens was detected.

\subsubsection{Immunolocalization of Ory $s$ in rice anthers}

The $2 \mathrm{DE}$ and immunoblot analysis results show that Ory s 2 proteins are expressed only in late stage pollen and anthers. To confirm pollen-specific expression of Ory s 2 , tissue localization of Ory s $2-B / C$ in cross sections of rice anthers was performed using immuno-light microscopy. The Orys $2-\mathrm{B} / \mathrm{C}$ is exclusively localized to the cytoplasm 

Figure. 5.4 Amino acid sequence alignment of Ory s 2-A, B and C with group II pollen allergens of other common grasses. Multiple sequence alignment was performed using ClustalX program (Thompson, 1997). The accession numbers and sources of the proteins are: Hol 12 (CAA10347) of velvet grass; Lol p II (CAA10350) of rye grass; Poa p 2 (CAA10348) of Kentucky bluegrass; Tri a 2 (CAA10349) of wheat; Phl p 2 (P43214) of timothy grass; Dac g 2 (CAA10345.1) of orchard grass and Cyn d 2 (CAA10346) of Bermuda grass. The "*" symbol indicates that the residues in that column are identical in all sequences in the alignment and the ":" and "." indicate that the residues in that column are conserved and semi-conserved, respectively. 


\begin{tabular}{|c|c|}
\hline Drys 2-A & 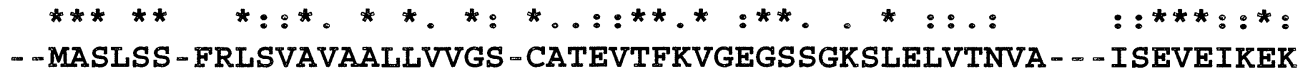 \\
\hline Drys2-B & - -MASLSS - FRLAVAVAALLVVGS-CATELTFKVAEGSSASSLELVTNVA - - - ISEVEIKEK \\
\hline rys $2-C$ & - -MASMSS - FRLAVAAAALLVIGS - CATELTFKVAEGSSATSLELVTNVA - - - ISEVEVKEK \\
\hline Hol & MSMASSSSSSLLAMAVLAALFAGAWCVPKVTFTVEKGSNEKHLAVLVKYEGDTMAEVELREH \\
\hline LolpII & MSMASSSSSSLLAMAVLAALFAGAWCVPKVTFTVEKGSNEKHLAVLVKYEGDTMAEVELREH \\
\hline Poap2 & MSMASSSSSSLLAMAVLAALFAGAWCVPKVTFTVEKGSNEKHLAVLVKYEGDTMAEVELREH \\
\hline Tria2 & MSMASSSSSSLLAMAVLAALFAGAWCVPKVTFTVEKGSNEKHLAVLVKYEGDTMAEVELREH \\
\hline PhlpII & MSMASSSSSSLLAMAVLAALFAGAWCVPKVTFTVEKGSNEKHLAVLVKYEGDTMAEVELREH \\
\hline Dacg2 & MSMASSSSSGLLAMAVLAALFAGAWCVPKVTFTVEKGS] \\
\hline & MSMASSSSSGLLAMAVLAALFAGAWCVI \\
\hline
\end{tabular}

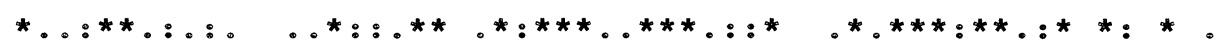

OrYs 2 - A GGKDWVALKESSTNTWSLKSEAALKGPFSVRFLVKNGGYRVVDDVIPESFTAGSEYKSGINV

OrYs2 -B GGKDWVALKESSSNTWTIKSEAPLKGPFSVRFLVKNGGYRVVDDVIPESFTAGSEYKSGIQL

OrYs2-C GGKDWVGLKESGSNTWTLKSEAPLKGPFSVRFLVKNGGYRVVDDVIPESFTAGSEYKSGIQL

Hol GSDEWVAMTKGEGGVWTFDSEEPLQGPFNFRFLTEKGMKNVFDDVVPEKYTIGATYAPEE - -

LOIPII GSDEWVAMTKGEGGVWTFDSEEPLQGPFNFRFLTEKGMKNVFDDVVPEKYTIGATYAPEE - -

Poap2 GSDEWVAMTKGEGGVWTFDSEEPLQGPFNFRFLTEKGMKNVFDDVVPEKYTIGATYAPEE - -

Tria2 GSDEWVAMTKGEGGVWTFDSEEPLQGPFNFRFLTEKGMKNVFDDVVPEKYTIGATYAPEE - -

PhlpII GSDEWVAMTKGEGGVWTFDSEEPLQGPFNFRFLTEKGMKNVFDDVVPEKYTIGATYAPEE-- 
Figure 5.5. A- A phylogenetic tree representing the alignment of Ory s 2 proteins with group 2 pollen allergens from other common grasses. The phylogenetic tree was constructed based on the distance matrix between sequence pairs using the MegAlign program of the DNASTAR software package (DNASTAR, Inc, Madison, USA). The scale at the bottom represents the substitution events between the sequence pairs. BThe taxonomic classification of 20 common allergenic grass genera according to Andersson et al (2003). 

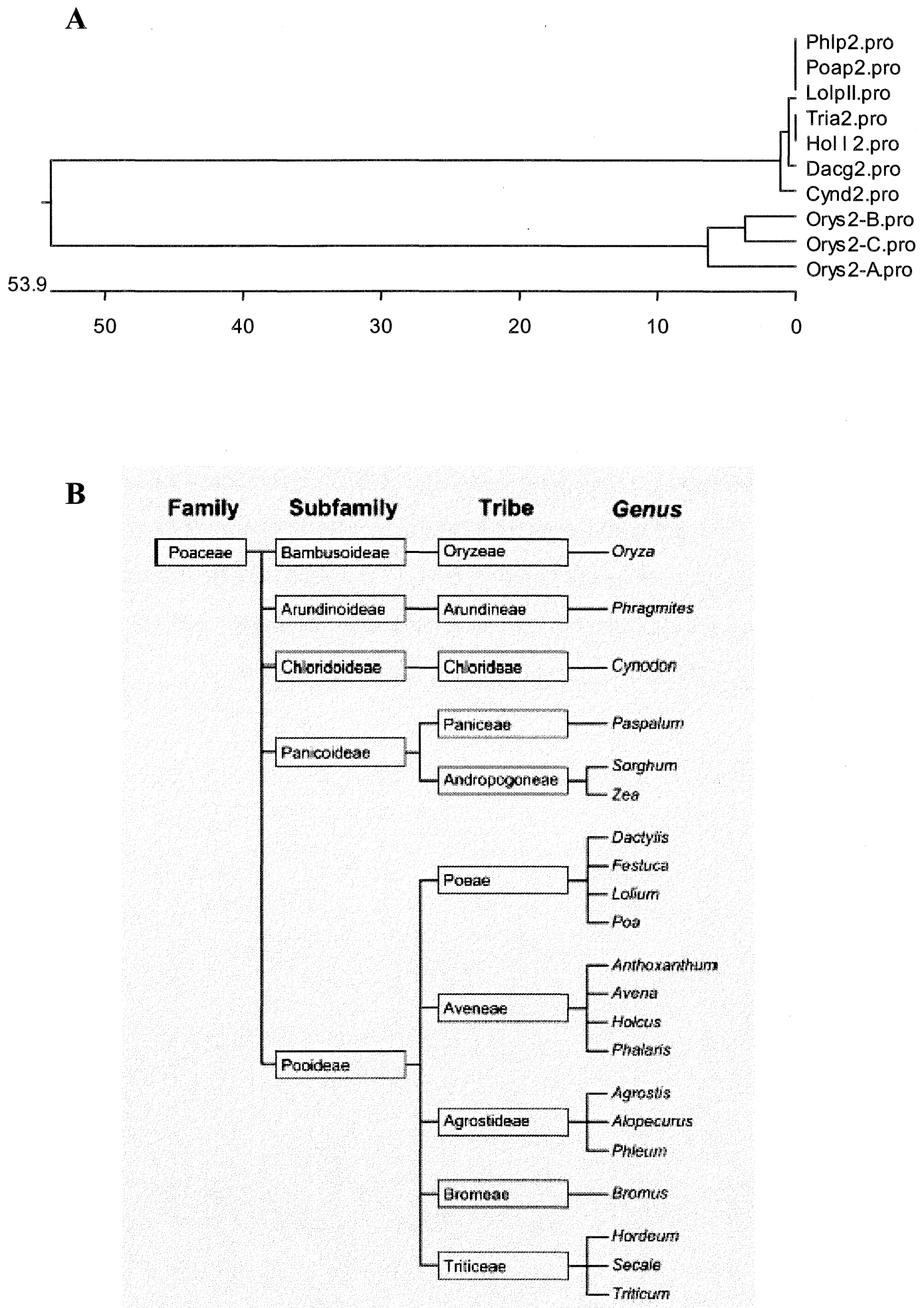
Figure 5.6. 2-DE immunoblot analysis using anti Ory s 2-A serum. $500 \mu \mathrm{g}$ of pollen protein extract was separated using a $11 \mathrm{~cm}$ IPG strip $(\mathrm{pH} 4-7)$ in the first dimension and SDS-PAGE in the second dimension. A. The separated proteins were electroblotted onto PVDF membrane and probed with anti Ory s 2-B/C serum using ECL-Plus western blot detection kit. The detection signals marked as Ory s 2-A and Ory s 2-B, C are corresponding to the protein spots t1-76 and t1-17 respectively in Figure 5.6-B. B. A replica gel of Figure 5.6-A was stained using colloidal coomassie and the protein spots corresponding to the detection signals in Figure 5.6-A are marked. 


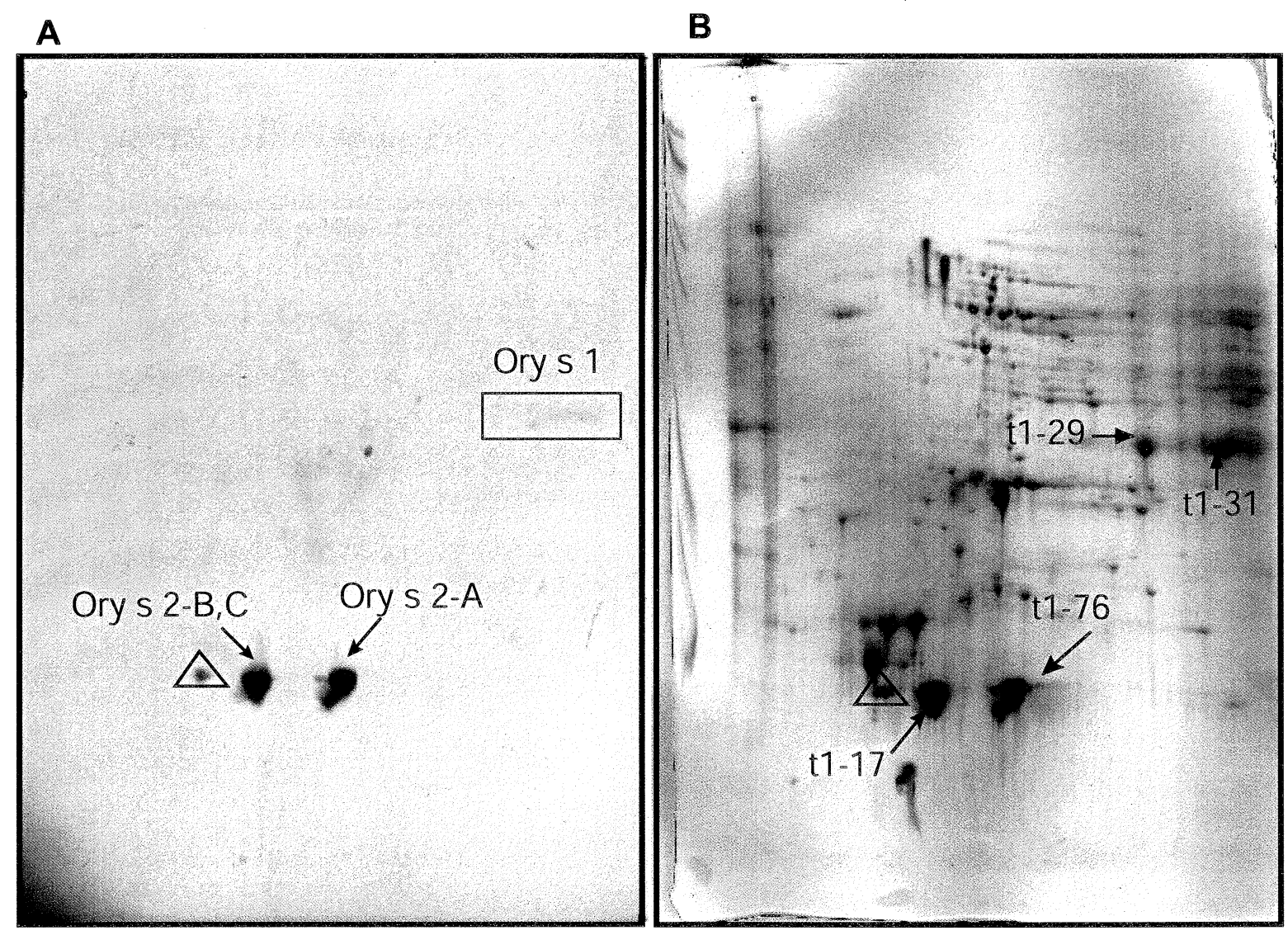


Figure 5.7. 2-DE immunoblot analysis using anti Ory s 2-B/C serum. $500 \mu \mathrm{g}$ of pollen protein extract was separated using a $11 \mathrm{~cm}$ IPG strip in first dimension and SDS-PAGE in second dimension. A. The separated proteins were electroblotted onto PVDF membrane and probed with anti Ory s 2-B/C serum using ECL-Plus western blot detection kit. The detection signals marked as Ory s 2-A and Ory s 2-B/C are corresponding to the protein spots t1-76 and t1-17 in Figure 5.7-B respectively. B. A replica gel of Figure 5.7-A was stained using colloidal coomassie stain and the protein spots corresponding to the detection signals in Figure 5.7-A are marked. 


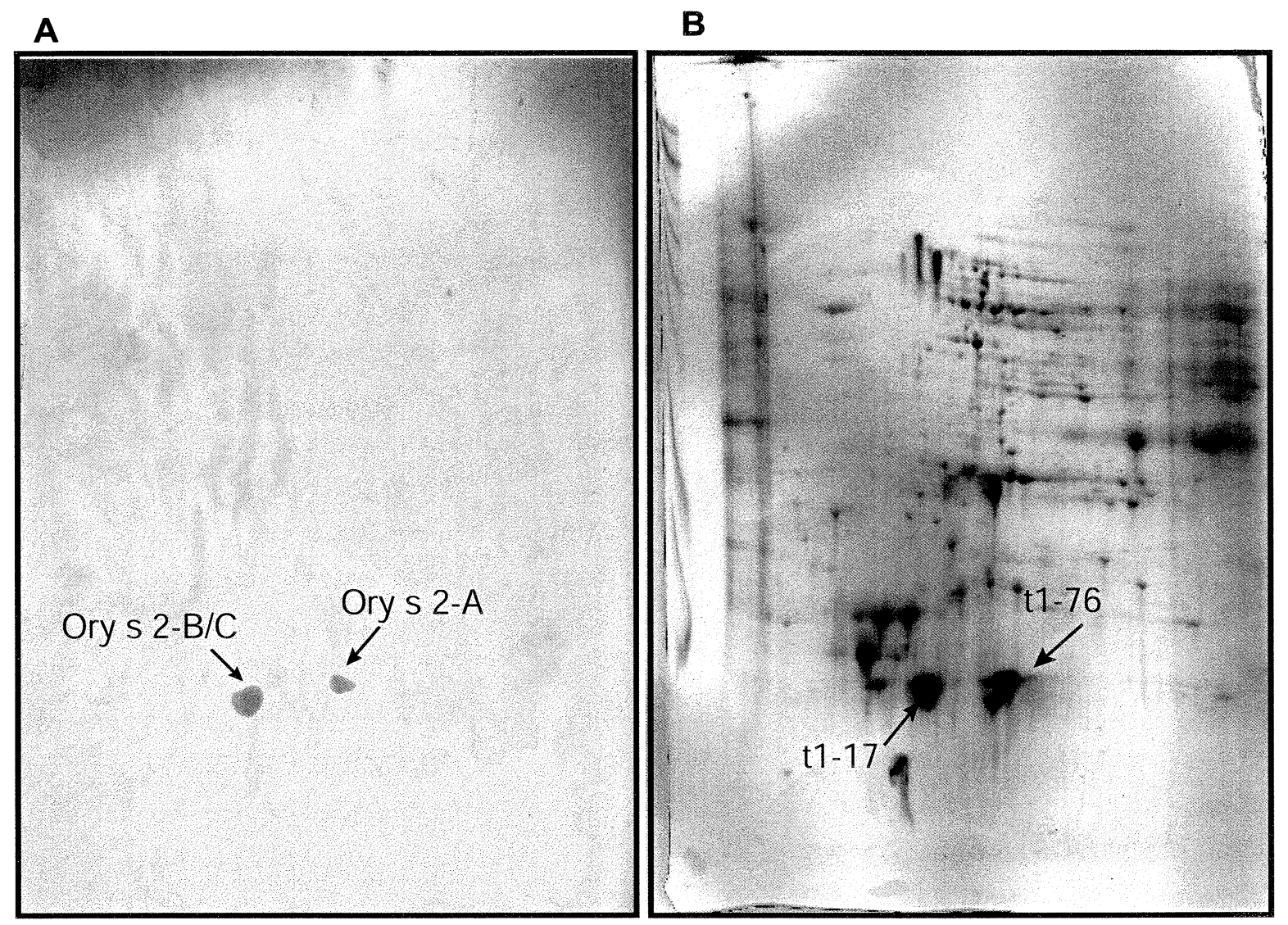


Figure 5.8. Stage and tissue specific expression of Ory s 2 revealed by western immunoblot analysis. Total soluble proteins, which were extracted from rice pollen and anthers at different developmental stages and from different tissues of rice plant, were fractionated by SDS-PAGE and electroblotted onto PVDF membrane. The blot was probed using anti Ory s $2-\mathrm{B} / \mathrm{C}$ antibody. Lane 1 , anthers at 8 days before heading $(\mathrm{DBH})$; lane 2 , anthers at $5 \mathrm{DBH}$; lane 3 ,anthers at $3 \mathrm{DBH}$ stage; lane 4 , anthers at heading stage; lane 5, pollen at heading stage; lane 6, leaf; lane 7, stigma; lane 8, shoot; lane 9 , root and lane 10, palea and lemma. Lane $\mathrm{C}$, heading stage pollen protein was probed using pre-immune serum as a negative control. 


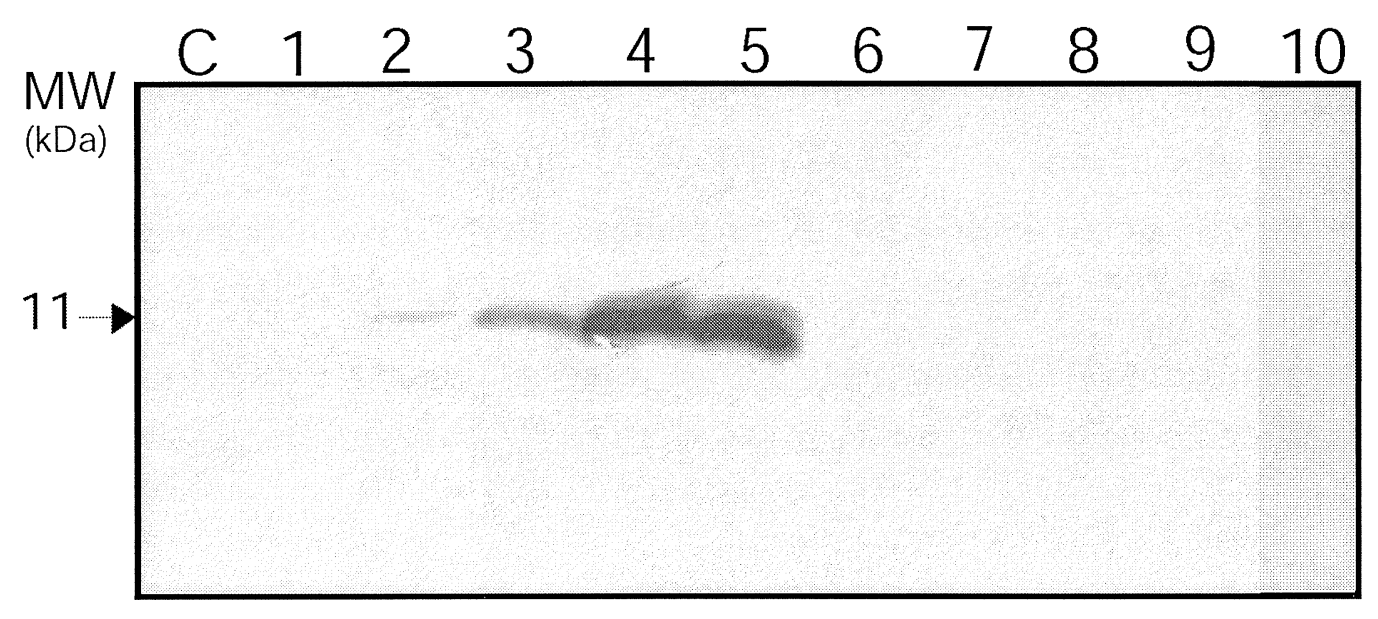


Figure 5.9. Cross-reactivity of Ory s 2-A antibody with group II allergens of other grasses. Soluble pollen proteins from Bermuda grass (lane 1), Kentucky blue grass (lane 2), timothy grass, perennial rye grass (lane 4), wheat (lane 5), maize (lane 6) and rice (lane 7) were separated by SDS-PAGE and blotted onto PVDF membrane. The blot was probed with anti Ory s 2-B/C antibody and detected with ECL-Plus detection kit. Lane $\mathrm{C}$, heading stage pollen protein was probed using pre-immune serum as a negative control. 


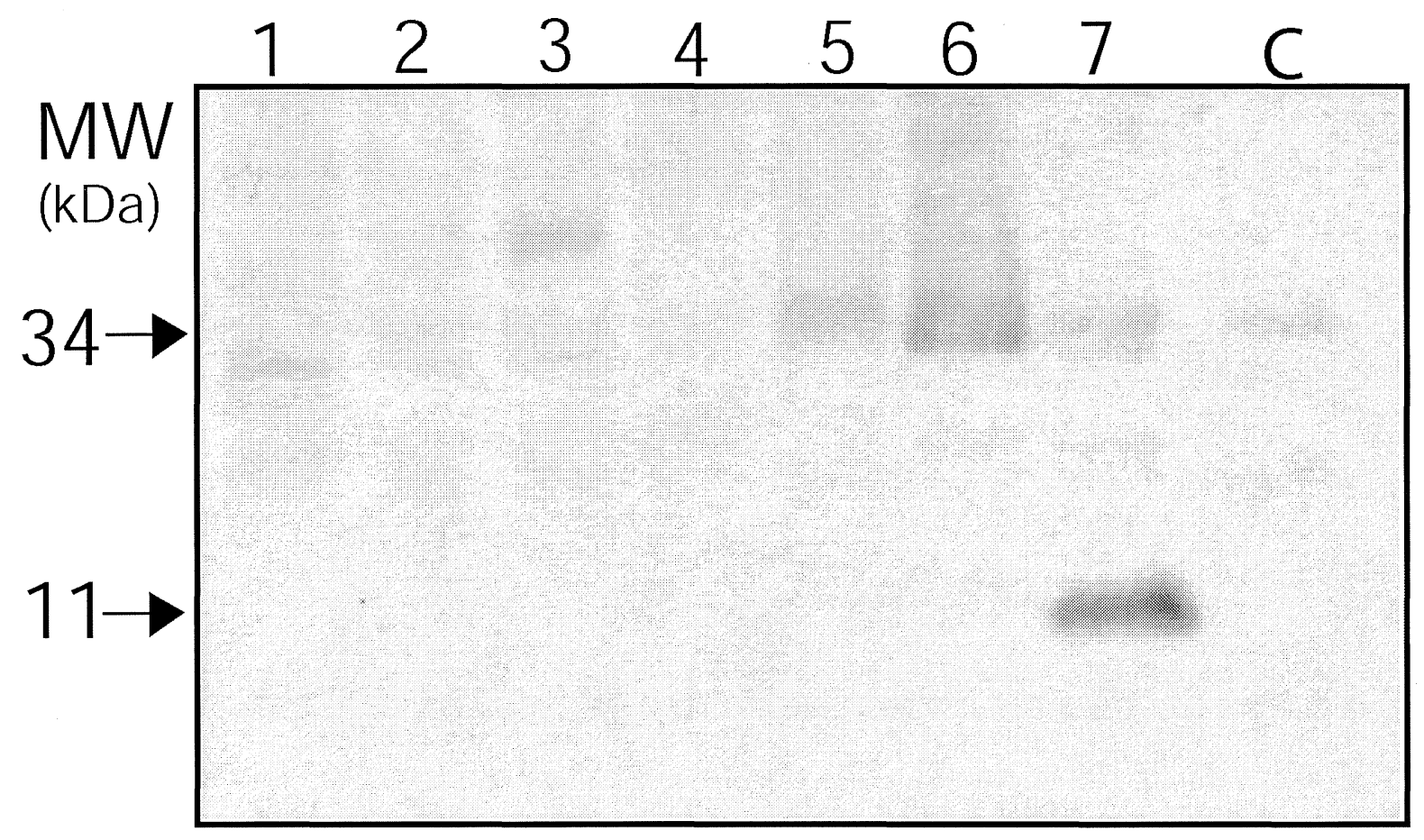



and cell wall of mature pollen (Figure 5.10), but no color reaction product was detected in the nuclei region of pollen and anther wall tissues. In control experiments using the pre-immune serum, the anther sections showed a low background color.

\subsubsection{Immunoprecipitation}

In order to examine if the Ory s 2 proteins interact with proteins of style origin in the rice flower, an attempt was made to co-immunoprecipitate Ory s 2 and other proteins (both anther and style origin) which can form a protein complex with Ory s 2 under native conditions. Figure 5.11 shows a coomassie stained gel of the immunoprecipitate of soluble protein fractions from the anthers at the heading stage and from the anthers, including style tissues, at the late heading stage using the Ory s $2-\mathrm{B} / \mathrm{C}$ antibody. Comparison of the protein profiles of immunoprecipitates of anthers and the anthers including styles did not reveal any difference. A band with a molecular weight of $11 \mathrm{kDa}$, which is corresponding to the Ory s 2 proteins, was present in both the immunoprecipitates that were performed with the Ory s $2-\mathrm{B} / \mathrm{C}$ antibody but not in the control experiments which were performed with pre-immune serum. As shown in Figure 5.11, there are a number of high molecular weight protein bands present in increased amount in the immunoprecipitates compared to the control experiment. But this result was not reproducible in a repeated experiment under the more stringent immunoprecipitation conditions.

\subsection{DISCUSSION}

Type I allergy is a prevalent global medical problem. Among the most potent elicitors of type I allergy are group II/III allergens of grass pollen. The group II allergens have been identified and characterised from a number of common grasses. However, so far there is no report on identification and characterisation of group II/III pollen allergens of rice, a widely cultivated crop plant and a member of the grass family. The accumulated rice EST and genome sequences in the public databases already contain partial or complete sequences of genes coding for some rice allergens. These databases have made it easier to identify these allergens using proteome analysis techniques without using immunological screening and cloning procedures. As described in Chapter 4, during our proteome analysis of rice male gametophyte development, the peptide mass fingerprinting and $N$-terminal amino acid sequence 
profiles of two late stage specific proteins were matched to the translation products of three unannotated EST sequences in public databases. Further investigations were carried out using immunochemical and bioinformatic research tools to further characterize the proteins.

Based on the sequence homology among deduced protein sequences of matching ORFs, it can be concluded that Ory s 2-A, Ory s 2-B and Ory s 2-C are homologous proteins. Cross-reactivity of the polyclonal antibodies to Ory s 2-A and Ory s 2-B/C protein spots on a 2-DE blot also supported this conclusion. The results of further bioinformatic analyses of matching $\mathrm{TC}$ sequences in combination with immunochemical analysis provided several lines of evidence that the three proteins are rice homologues of group II pollen allergens of the grass family. First, the deduced amino acid sequences of the matching ESTs have 23 amino acid long signal peptide sequences. Furthermore, these signal peptide sequences share around $45 \%$ of sequence identities with signal peptides predicted for other well-characterised group II allergens of other grasses. This means that Ory s 2 proteins are likely to be secreted, which is one of the common characteristics of pollen allergens. Second, the experimental and calculated molecular weights and pIs of the protein spots on 2-DE gels are in close agreement with molecular weights and pIs of group II pollen allergens from the grass family. They exist as immunologically indistinguishable multiple isoforms in the $\mathrm{pI}$ range of 5.0-5.4 as it was reported for Lol pII (Ansari et al. 1989b; Dolecek et al. 1993). Third, they share comparable sequence identities with other group II pollen allergens as demonstrated by sequence alignment analysis. At the same time, conserved pollen allergen domains and some other sequence motifs that are specific to grass pollen allergens are also present in Ory s 2 proteins. Fourth, the Ory s 2 sequences have $39 \%$ of amino acid sequence identity with the C-terminal portion of Ory s 1 (group I pollen allergen of rice). It was reported in rye grass that Lol pII also shares a similar level of sequence identity (33\%) with the C-terminal part of Lol pI (Griffith et al. 1991). Finally, the temporal and spatial expression patterns of Ory s 2 proteins demonstrated by immunochemical experiments are consistent with the expression pattern of Ory $\mathrm{s} 1$ and other group II allergens (Dolecek et al. 1993; Xu et al. 1995a). The evidence presented above indicates that these three proteins are the rice homologues of grass group II pollen allergens. Therefore, we designated them as Ory s 2-A, Ory s 2-B (OSJNBa0050F15.10) and Ory $\mathrm{s}$ 2-C (OSJNBa0050F15.9) according to the 

Figure 5.10. Immunolight microscopic localisation of Ory s 2 on cross sections of heading stage rice anthers. A. The semi-thin anther cross sections were probed with anti Ory s 2-A antibody and detected with NBT/BCIP colour reaction substrate. The insert shows one pollen grain at higher magnification. The colour reaction product was detected in cytoplasm and cell wall of pollen grains. B. The anther cross sections were treated with pre-immune serum and detected in parallel with $\mathbf{A} .($ Bars $=100 \mu \mathrm{m})$ 


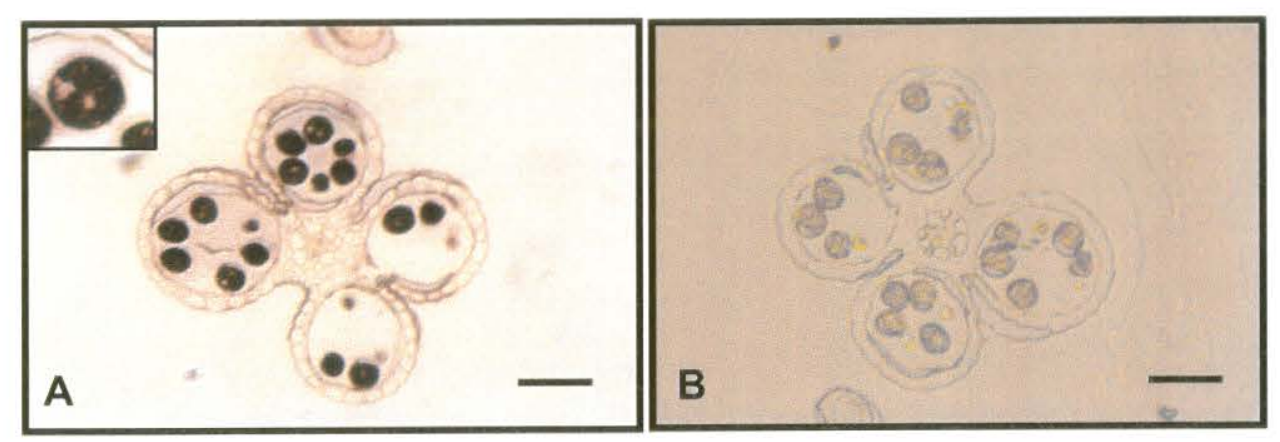


Figure 5.11. Immunoprecipitation of anther and style proteins using anti Ory s 2-B/C antibody. Proteins were extracted under native conditions from anthers plus styles (lane 2 and lane 3) and from anthers alone (lane 4 and lane 5) at the heading stage. Immunoprecipitation experiments were carried out using anti Ory s 2-B/C serum (lane 2 and lane 4). The control experiments were also performed in parallel using the preimmune serum (lane 3 and lane 5). The precipitated proteins were separated using Novex precast $10-20 \%$ Tricine gels and visualised by colloidal coomassie staining. Protein standards were co-migrated in lane 1 . Arrows indicate the heavy and light chains of IgG in the immunoprecipitant. A band corresponding to Ory s 2 is also indicated by an arrow. 


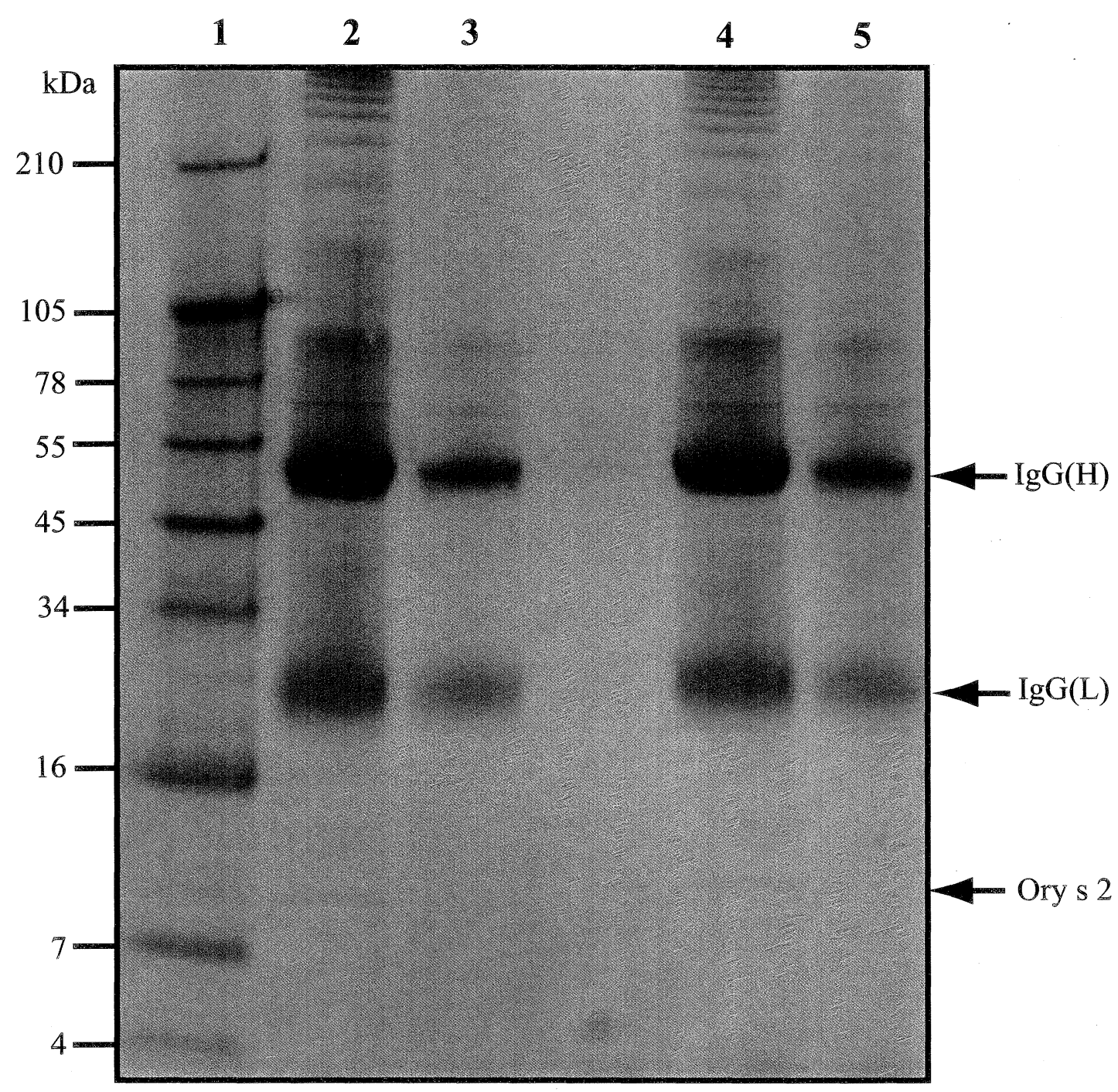



international allergen nomenclature system (King et al. 1994). The $N$-terminal amino acid sequence of Ory s 2-A protein was submitted to the SWISS-PROT protein database with accession number P83466, and the submission of $N$-terminal sequences of Ory s 2$\mathrm{B}$ and Ory s $2-\mathrm{C}$ is pending. The unavailability of serum from patients who are allergic to rice pollen prevented further investigations into the allergenic properties of this group of protein using immunochemical techniques.

Early studies show that grass pollen allergens that belong to the same allergen group but from different grass origins have immunological cross-reactivity (Smith et al. 1994a; Smith et al. 1994b). Furthermore, cross-reactivity of Ory s 1 with group I allergens from timothy, rye and orchard grasses has been demonstrated $(\mathrm{Xu}$ et al. 1995b). In this report it is evident from the sequence alignment analysis that Ory s 2 proteins share a considerable level of sequence similarity with group II allergens from other grasses. Therefore, we expected some degree of cross-binding of the anti-Ory s 2 antibody to group II allergens of other common grasses. However, our immunoblot analysis showed that polyclonal the anti-Ory s 2 antibody of rice plant, which is a member of grass subfamily Bambusoideae, does not cross-bind to the counterparts from other three grass subfamilies including Pooideae (rye grass, Kentucky blue grass, timothy grass and wheat), Chloridoideae (Bermuda grass) and Panicoideae (maize). A possible explanation for this is that the allergenic epitopes of group II allergens are probably not very conserved among the grass subfamilies. The close conformation between the phylogenetic relationship among the group II allergens and the taxonomic classification of 20 common grass genera also supports this explanation (Figure 5.5). Another factor likely to contribute to a lack of cross-reactivity between group II allergens is the molecular size of group II allergens. The small molecular size of group II allergens may reduce the probability of conservation of common allergenic epitopes among group II allergens from different grass origins. Therefore, a lower level of crossreactivity among the group II allergens than that of among the group I allergens can be expected. However, the Ory s 2 antibody cross bound to a $\sim 32 \mathrm{kDa}$ protein band in maize pollen extracts. These proteins presumably are the group I allergens of maize and they have some conserved cross-reactive epitopes with Ory s 2. Zea mI, the group-I pollen allergens of maize, have been identified and characterized using molecular and immunochemical tools and displayed cross-reactivity to group I allergens from other grasses (Broadwater et al. 1993). The cross-reactivity between Ory s 2 and other grass 
group II pollen allergens needs to be further studied using IgE from rice pollen allergic patients. Further study on immunological features of rice group II pollen allergens may lead to the application of these allergens for the immunotherapy of rice pollen allergy.

Although the allergic properties of grass pollen allergens have been studied intensively by immunologists, their native biological functions in plant reproductive developmental process are not very well understood. In terms of biological function, the group I allergens are the best-studied group among the eleven groups of grass pollen allergens. Cosgrove et al. reported that group I pollen allergens share low level of sequence homology with expansins and they also demonstrated in-vitro cell expansion activities in grass cell walls. Therefore the group I pollen allergens were classified as $\beta$ expansin family (Cosgrove et al. 1997). However, the biochemical mechanism underlying expansin activities of group I allergen remains highly controversial as different biochemical activities were proposed to group I allergens (Grobe et al. 1999; Grobe, Poppelmann et al. 2002; Li and Cosgrove 2001). The considerable level of sequence similarity and existence of some common functional domains between Ory s 2 and Ory s 1 raise the question of whether Ory s 2 also has expansin activity. Until now, there is no report in scientific journals about the physiological function of group II pollen allergens.

The developmental stage specific expressions and the high abundance of Ory s 2 proteins in mature pollen revealed by our investigation indicates that these proteins should have important functions in pollen development and pollen stigma interactions. In order to gain some knowledge about the biological function of group II allergens, attempts was made to immunoprecipitate and subsequently identify proteins of pollen and style tissue origins which bind to Ory s 2 in native biological conditions. No conclusive differences were observed between the SDS-PAGE profiles of test and control experiments. Optimization of the immunprecipitation conditions through more repeated experiments was not pursued further because of the limited availability of rice anthers and styles.

Elucidation of the exact biological function of group II allergens using immunochemical and biochemical assays and molecular biology tools in the future will contribute to the better understanding of molecular mechanisms underlying the male 
gametophyte developmental processes and also to the elucidation of the precise biological functions of other grass pollen allergens in plant development. 



\section{CHAPTER 6 GENERAL DISCUSSION}

\subsection{INTRODUCTION}

In the post-genome sequencing era, proteomics has become an important functional genomics tool providing biological information at the protein level, and has been widely applied to different aspects of the life sciences. The ability of proteomics to deal with large-scale determination of gene and cellular function at the protein level means that it can be used to comprehensively characterize the complex molecular networks underlying various biological processes. This study was directed at investigating the usefulness of 2-DE-based comparative proteomics to study the changes in global protein expression during the male gametophyte development in rice plants, and demonstrates how the potential of this technique can be realized when applied to real biological problems.

\subsection{THE ACHIEVEMENTS OF THIS THESIS}

\section{Chapter 3:}

- The male gametophyte developmental process in rice cultivar Doongara was studied to identify unique cytological "markers" for the major cellular events which take place inside the developing anther.

- The allometric relationships between different cytological events and vegetative growth measurements such as anther length, auricle distance and the days before heading were used to define discrete developmental stages in male gametophyte development in rice cultivar Doongara. This enabled the collection of near homogenous anther populations for each developmental stage.

\section{Chapter 4:}

- $\quad$ Anther proteome maps were established within the $\mathrm{pH}$ ranges of 4-7 and 6-11 for six microspore developmental stages. More than 3,500 protein spots were detected by silver staining in the combined $\mathrm{pH}$ range of $4-11$.

- Comparison of the proteome maps revealed that the expression levels of 150 protein spots changed at different stages during the development. Putative identities 
were assigned to 49 protein spots by peptide mass fingerprinting analysis. A further eight low molecular weight protein spots were identified by $\mathrm{N}$-terminal sequencing.

- The integration of the protein expression and identification data demonstrated the active participation of three different signaling and metabolic pathways in the later stages of pollen development.

\section{Chapter 5:}

- Three isoforms of developmentally expressed rice homologues of grass group II pollen allergens (Ory s 2) were identified and characterized using bioinformatics. The N-terminal sequence of one isoform has been deposited in the public protein database

- $\quad$ Polyclonal antibodies were produced against Ory s 2 proteins using gelseparated and nitrocellulose-bound proteins as the antigen. The antibodies were used for the further characterization of these proteins.

- Rice group 2 pollen allergens displayed low levels of sequence similarity and cross reactivity with their counterparts from other common grasses.

\subsection{RICE AS A MODEL SYSTEM FOR MALE GAMETOPHYTE RESEARCH}

One of the achievements of this thesis is its contribution to the use of rice plants as a model system to study the male gametophyte development.in crops. As outlined in section 1.2.4.3, several features of rice plants make them an ideal model system for plant research (Goff 1999; Izawa and Shimamoto 1996; Salse et al. 2002). These include the availability of the complete draft rice genome sequence and the large number of rice EST sequences, both of which are critical to the use of peptide mass fingerprinting for high-throughput identification of proteins from 2-DE gels. The only impediment to the use of rice as a model for the study of male gametophyte development is the relative difficulty of collecting sufficient amounts of homogenous anther materials at the different developmental stages. This bottleneck is caused by the small size of rice anthers and the heterogeneous maturation pattern of rice flowers on the rice panicle. The cold susceptible Australian rice cultivar Doongara was chosen for this project with the expectation that the experimental results of this project can be 
integrated with other ongoing research projects of our group investigating the coldinduced male sterility in rice using the same cultivar. As presented in Chapter 3, the extensive cytological and growth analyses were conducted in this cultivar to define the allometric relationship between growth measurement and microspore developmental stages. These studies provided the basis for the selective collection of a homogenous anther population for each predefined microspore developmental stage. In combination with continuous plant growth throughout the year under a controlled environmental facility, the micro dissection of rice spikelets provided sufficient anther materials for proteomic profiling of male gametophyte development.

The research on this model system resulted in the identification of new male gametophyte-specific genes and also in the detection of molecular networks which are active in the developing rice anthers. Further exploitation of this approach promises to generate further insight into plant reproductive development.

\subsection{PROTEOMICS AS A RESEARCH TOOL TO STUDY MALE GAMETOPHYTE DEVELOMENTAL PROCESS}

In the post genomic era, proteomics has emerged as a valuable analytical tool to deal with the analysis of whole genome at the protein level. The unparalleled capacity of 2DE to simultaneously display thousands of proteins has been utilized in plant research to differentially display the protein contents of various plant tissues under particular physiological conditions, such as biotic and abiotic stresses and plant microbe interactions (Imin, Kerim et al. 2001; Natera, Guerreiro et al. 2000; Rossignol 2001; van Wijk 2001). In order to expand the application of proteomics in plant science, this thesis set out to systematically investigate one of the fundamental reproductive developmental processes in plants using 2-DE based comparative proteomics. The proteome maps of six developmental stages of anthers were established, new proteins were identified and some of the metabolic and signaling pathways involved in rice anther development were detected. Overall, the primary findings of this thesis demonstrated the potential of applying proteomics to other aspects of plant developmental biology.

However, it also became apparent that the current 2-DE based proteomics technology is not free from problems. Protein solubility and the ability to detect low 
abundance proteins are major limitations, which results in the incomplete representation of proteomes on 2-DE gels. Hydrophobic proteins, which represents up to $30 \%$ of the genome coding capacity of eukaryotic cells (Wallin and von Heijne 1998), are generally underrepresented in proteome maps due to their low solubility in currently available detergents which are compatible with 2-DE. The total number of predicted genes from draft sequences of japonica rice genome range from 32,000 to 61,000 (Delseny 2003; Goff, Ricke et al. 2002). In this study, the 3,500 rice anther proteins displayed on 2-DE gels only accounts for $10 \%$ of the minimum coding capacity of the rice genome, assuming one gene product per estimated gene. This figure will decrease further if the number of protein isoforms detected in this study is taken into the account. Furthermore, the transcriptional analyses of pollen gene expression in monocot plants have estimated that about 20,000 and 24,000 different mRNAs are present in the mature pollen grains of Tradescantia and maize, respectively (Mascarenhas 1990). If it is assumed that the similar numbers of genes are expressed in rice pollen, the proteins detected on the anther 2-DE maps could not fully reflect the true complexity of eukaryotic gene expression.

Another major limitation lies in the area of post-separation protein identification techniques. As shown in Chapter 4, the success rate with protein identification by PMF analysis was lower than expected in this study. The protein identification by $N$-terminal analysis and peptide mass fingerprinting of eight protein spots using the same database resulted in the totally different success rates. The eight protein spots, which had not been identified by PMF analysis, were successfully identified by $N$-terminal sequencing analysis. This indicated that the under representation of the matching database entries was not the main reason contributing to the failure of protein identification of these eight protein spots by PMF analysis. Furthermore, the searches of different databases using the same PMF data also resulted in different success rates (section 4.3.3). These examples highlighted the imperfectness of PMF analysis and the importance of database quality in the success rate of protein identification. The real capacity of proteomics can be fully utilized if only the complete or near complete proteome of a tissue or cell is successfully displayed and every protein is identified.

The current experimental limitations in 2-DE based proteomics can be reduced in a number of ways. Solubilisation of hydrophobic proteins can be improved by the application of new zwitterionic detergents (Chevallet et al. 1998) and by sequential 
extraction of the sample with reagents of increasing solubilizing power (Molloy et al. 1999). Detection and identification of highly hydrophobic proteins can also be achieved by MudPIT technology which based on chromatographic separation of peptides generated from a complex protein mixture (Koller et al. 2002) One dimensional SDS PAGE, which is compatible with solubilisation of membrane proteins using SDS, can also used to the separation of highly hydrophobic proteins, even though the resolution of this technique is much lower than 2-DE analysis (Andon et al. 2002) Separation of protein samples using narrow range (1 pH unit) IPG strips to generate overlapping proteome contig maps (Cordwell et al. 2000) and the enrichment of low-abundance proteins by preparative isoelectric pre-fractionation step using a multi-compartment electrolyser (MCE) can contribute to the visualization of low-abundance proteins (Herbert et al. 2001).

\subsection{GLOBAL CHANGES IN PROTEIN EXPRESSION DURING THE RICE MALE GAMETOPHYTE DEVELOPMENT}

The establishment of 2-DE based proteomics as a viable differential display tool has enabled the investigation of global changes in gene expression of a biological system at the protein level. As presented in Chapter 4, while the global expression pattern of rice anther proteins was largely unaltered, the comparisons of rice anther proteome maps showed that the expression level of 150 proteins changed more than two fold during the course of anther development. These 150 proteins account for less than $5 \%$ of the total proteins that were visualized on 2-DE gels. Most significant changes in protein expression levels were detected between the proteome maps of the pollen mother cell stage and the heading stage. More than 50 new protein spots were newly expressed at the heading stage compared to the pollen mother cell stage.

Transcriptional profiling studies of male gametophyte development showed that in pollen grains of Tradescantia and maize, the male gametophyte specific genes could be classified into "early" and "late" genes (Mascarenhas 1990). According to those studies, most of the "early" genes were transcriptionally active just after pollen meiosis. The "late" genes become active soon after first pollen mitosis and are thought to play major roles during the later part of pollen maturation and during pollen germination. The transcripts of some "late" genes are stored untranslated in pollen grains until pollen germination (Stinson, Eissenberg et al. 1987). The late stage-specific proteins that were 


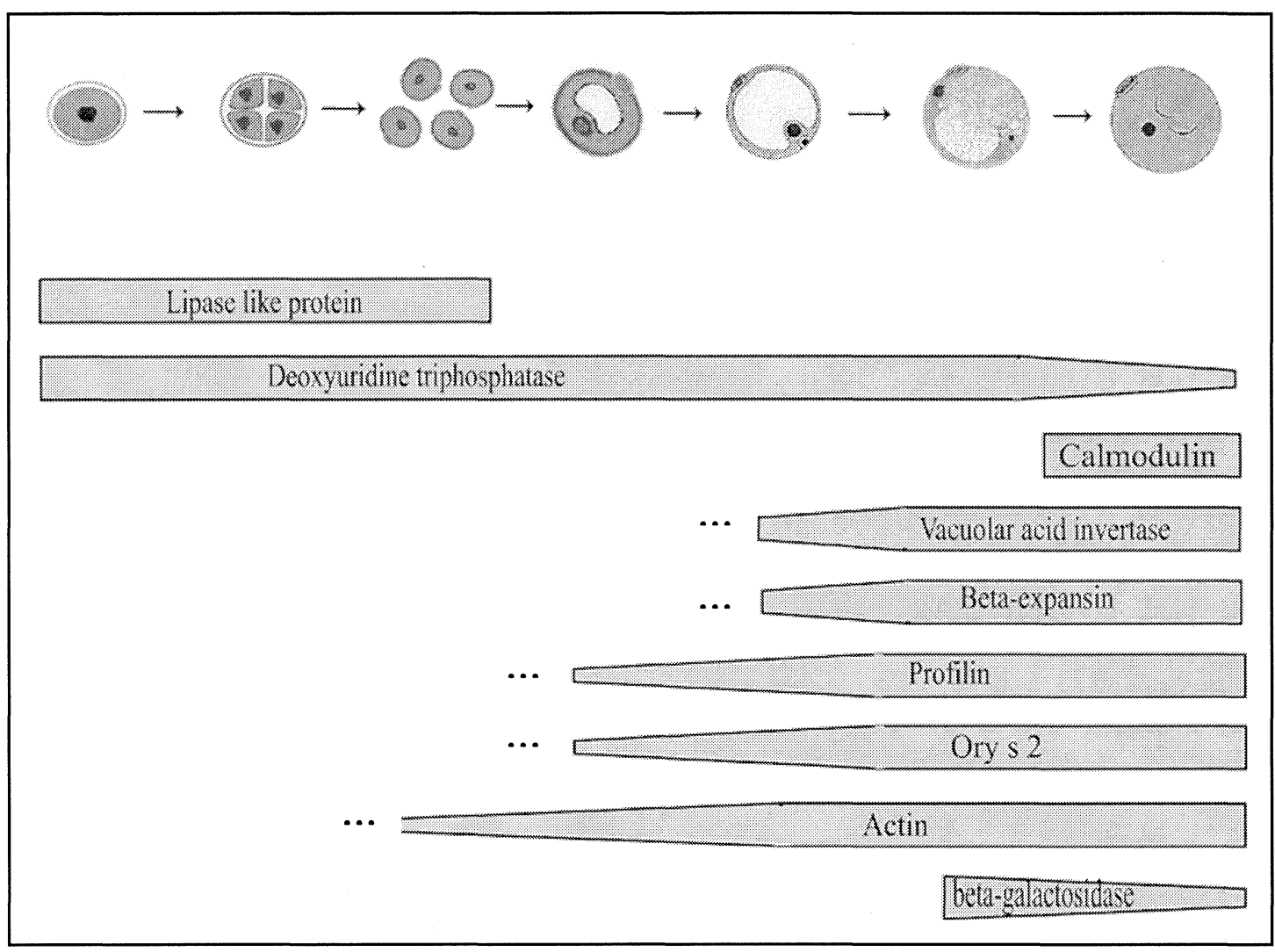

Figure 6.1. Temporal expression patterns of some differentially displayed protein identified in this study.

detected in this study are presumably the products of the "late" genes, because the expression of most of these proteins starts at around the first pollen mitosis (Table 4.1, Chapter 4), which conforms to the above-mentioned temporal expression pattern of "late" genes. Furthermore, the comparison of proteome maps also revealed a small number of proteins representing the "early" class gene products. However, the number of the detected early stage-specific proteins is much less than those of late stage-specific proteins in this study. A possible explanation for this is that the abundance level of "early" gene products is probably below the limit of detection of the silver staining used in this study. It is also possible that some transcripts of the "early" genes remain untranslated until the onset of certain later stages. The examples of "early" and "late" gene products, which were identified in this study, are shown in Figure 6.1. These results of this study clearly demonstrate the potential power of proteomics to test and complement the transcriptional profiling studies at the protein level. 


\subsection{METABOLIC AND REGULATORY PATHWAYS INVOLVED IN POLLEN DEVELOPMENT}

Out of the 150 differentially displayed protein spots, 49 proteins were tentatively identified by PMF analysis and eight proteins by $\mathrm{N}$-terminal sequencing and homology searches. In order to better understand the molecular networks in which these proteins are involved, putative functional classifications were assigned to the identified proteins according to the functional classifications in A. thaliana and M.trancatula proteome projects (Kaul, Koo et al. 2000; Mathesius, Keijzers et al. 2001). A statistical summary of the functional classification is shown Figure 6.1. Largest group of proteins (26\%) are involved in metabolism and the next largest group matched to hypothetical or unknown proteins. Unlike other studies, the proteins involved in cell wall and cytoskeleton formation constituted the third largest group (18\%), perhaps indicating the importance of these processes in pollen development. Several functional protein classes such as cell signaling and protein synthesis that have been identified in other projects are underrepresented, probably because of the low number of identified proteins in this study.

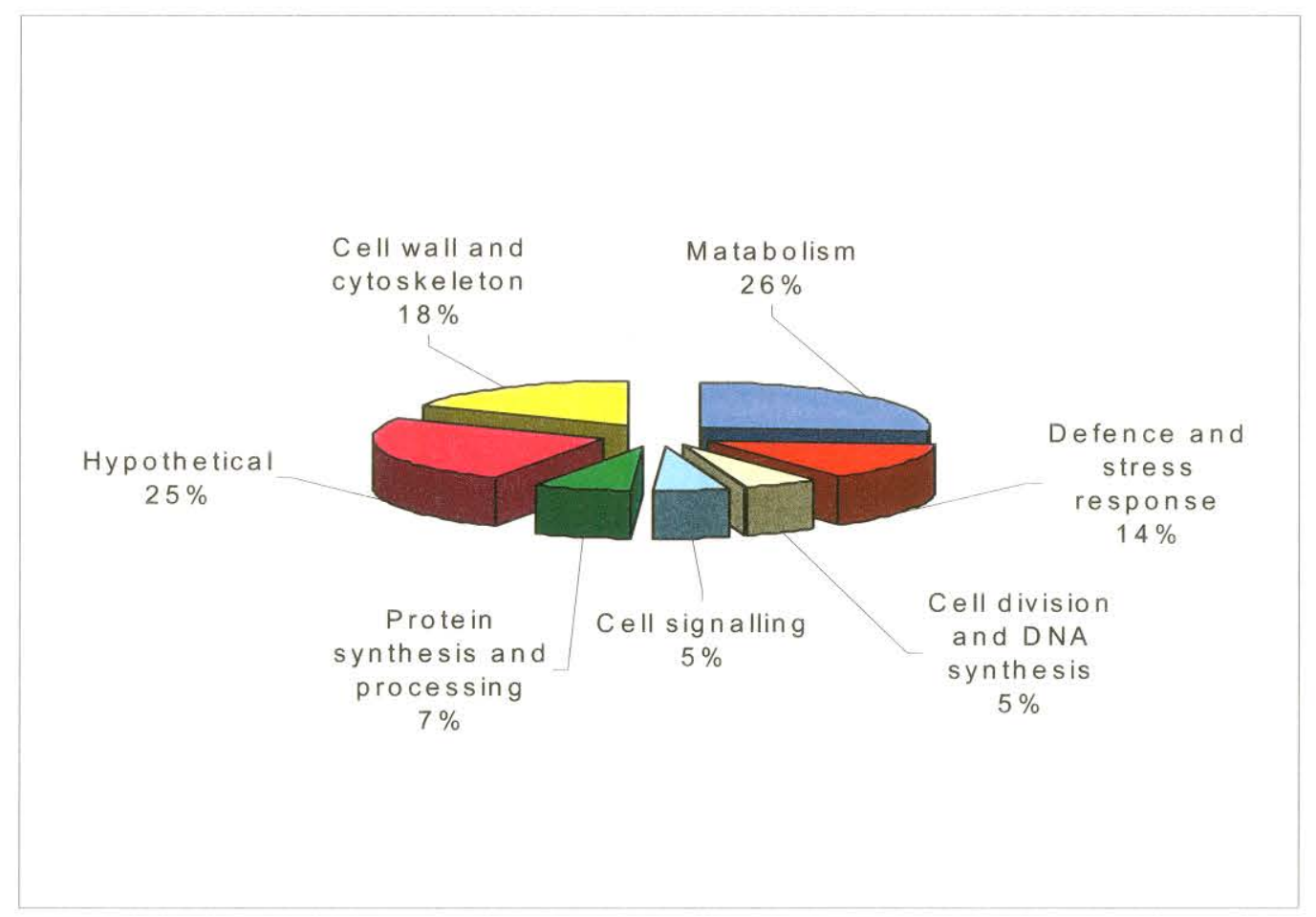

Figure 6.2. Summary of the functional classification of the identified rice anther proteins. 
Based on the predicted identities of the limited number of differentially displayed anther proteins and their temporal regulation patterns, three developmentally regulated metabolic or regulatory pathways were identified that are active in developing rice anthers. Table 6.1 lists the predicted identities of three groups of proteins and their proposed biological functions in cellular processes in which they are involved. The ubiquitin/26 proteosome pathway, of which three components were identified, is involved in the selective proteolysis of proteins in plants (discussed in Chapter 4). Recent analysis of Arabidopsis thaliana genome revealed that a sizable fraction ( $\sim 5 \%)$ of the plant proteome is devoted to encoding the components of this pathway and the individual components are connected to almost all aspects of plant biology ( $\mathrm{Fu}$ et al. 1999; Vierstra 2003). The up-regulation of two components indicates the possible role of COP9 signalosome-mediated light signal sensing in anther dehiscence at the flowering stage. The up-regulation of three proteins involved in starch and sucrose metabolism at later stages of pollen development coincides with the increased starch synthesis activity in pollen grains. Late stage-specific expression of B-expansin, profilin and actin conforms to their proposed function in cell wall expansion and pollen stigma interaction.

Considerable portion of the identified proteins in this study are primary metabolic enzymes which are involved in basic "housekeeping" metabolic processes in plants. However, it is possible that these housekeeping proteins have other function(s) during

Table 6.1. Summary of the proteins involved in metabolic pathways

\begin{tabular}{|c|c|c|c|}
\hline $\begin{array}{l}\text { Ubiquitin / } 26 \\
\text { proteosome }\end{array}$ & $\begin{array}{l}\text { Jab } 1 / C \text { CS5 } \\
\text { Ubiquitin } \\
20 S \\
\text { proteosome }\end{array}$ & $\begin{array}{c}\text { Isoform } \\
\text { number } \\
1 \\
1 \\
1\end{array}$ & $\begin{array}{l}\text { repression of photomorphogenesis } \\
\text { protein degradation } \\
\text { protein degradation }\end{array}$ \\
\hline $\begin{array}{l}\text { Starch /sucrose } \\
\text { metabolism }\end{array}$ & $\begin{array}{l}\text { Vacuolar acid } \\
\text { invertase } \\
\text { Fructokinase II } \\
\text { Beta- } \\
\text { galactosidase }\end{array}$ & $\begin{array}{l}2 \\
2 \\
2\end{array}$ & $\begin{array}{l}\text { hydrolysis of sucrose } \\
\text { fructose phosphorylation } \\
\text { hydrolysis of O-glycosides }\end{array}$ \\
\hline $\begin{array}{l}\text { Cell wall and } \\
\text { cytoskeleton }\end{array}$ & $\begin{array}{l}\text { Actin } \\
\text { Profilin } \\
\text { Beta-expansin } \\
\text { Group II } \\
\text { allergens }\end{array}$ & $\begin{array}{l}1 \\
3 \\
3 \\
3\end{array}$ & $\begin{array}{l}\text { cytoskeleton formation } \\
\text { actin binding } \\
\text { cell wall loosening } \\
\text { cell wall loosening?? }\end{array}$ \\
\hline
\end{tabular}


the male gametophyte development in anthers in addition to their main role in primary metabolism. Recent studies showed that some proteins could "moonlight", or have more than one distinct function in an organism. Therefore, they are called moonlighting proteins (Jeffery 1999). The function of moonlighting proteins can vary as a consequence of changes in cellular localization, cell type, oligomeric state, or the concentration of a ligand, substrate, cofactor or product. One of the identified proteins in this study, quinone oxidoreductase, has been reported to have moonlight functions in animals (Piatigorsky 1998). Recent results by the Johnston et al. show that the regulatory proteins of $26 \mathrm{~S}$ proteosome complex, of which a subunit was identified in this study, has a role in nucleotide excision repair and transcription elongation (Gonzalez et al. 2002; Jeffery 2003). This moonlighting mechanism of proteins adds another dimension to the cellular complexity of eukaryotic gene expression.

Regarding the significant cellular changes that take place inside anthers during the development, the differential protein expression profiles that were obtained in this study are probably an under representation of protein changes in developing anthers. Therefore, it is still inadequate to provide a full insight into the molecular mechanism of male gametophyte developmental process. Complete achievement of such a goal in this study was impeded mainly by the current limitations in 2-DE and protein identification techniques (discussed in section 1.3.5).

\subsection{FUNCTION OF IDENTIFIED PROTEINS IN COLD INDUCED MALE STERILITY}

One of the aims of this study is to assist the research projects aimed at understanding the molecular mechanism of cold-induced male sterility in rice (abnormal development) by providing information about proteins involved in the normal development of rice anthers. Two of the identified proteins in this study, $\beta$-expansin and nucleoside diphosphate kinase, have been found to be involved in cold-induced male sterility in rice anthers by proteomic analysis (Imin 2002). An increase in the partial degradation or cleavage of these proteins was detected in trinucleate anthers which had been treated with cold shock at the young microspore stage. The involvement of $\beta$ expansin in the process of cold-induced male sterility suggests that the sterility resulting from cold treatment is possibly partially attributed to incomplete pollen tube growth. In 
the same study, the $\beta-6$-subunit of $20 \mathrm{~S}$ proteosome was identified and observed to be up-regulated by two fold in response to cold treatment at the young microspore stage. The identification of another subunit of the 20S proteosome and other constitutes of ubiquitin-proteosome pathway in our study provided further information about the cellular processes in which this cold responsive protein ( $\beta$-6-subunit of $20 \mathrm{~S}$ proteosome) is involved (section 4.4.1). Future studies in cold-induced male sterility can be directed at the stage-specific anther proteins and the relevant biological pathways identified in this project. This will contribute to the understanding of molecular mechanism of the stress-response process in plants.

\subsection{BIOLOGICAL FUNCTION OF POLLEN ALLERGENS IN PLANT REPRODUCTION}

Grass pollen allergens have been studied extensively since the 1960s, and to date, eleven different groups of grass pollen allergens have been identified and characterised from one or more species (Andersson and Lidholm 2003; Suphioglu 2000). The pollen allergens have been poorly characterized in terms of their biological function in plants, although their immunological features have been well studied. Out of the eleven groups of pollen allergens characterised in grasses, biological functions have been proposed for only a few groups based on the sequence homology to other known proteins or based on the results of in vitro biochemical assays (Andersson and Lidholm 2003). The group I allergens are thought to have an expansin activity and to play important roles in pollen tube growth during fertilization (Cosgrove 1997; Cosgrove, Bedinger et al. 1997). The group 5 allergen of timothy grass pollen has been proposed to have ribonuclease activity (Bufe et al. 1995). The profilins are involved in signalling pathways that regulate the pollen cytoskeleton remodelling during the pollen engorgement and pollen tube growth (Vidali and Hepler 2001).

In this study, multiple isoforms of three groups of rice pollen allergens have been identified. These allergens included three isoforms of group I allergen ( $\beta$-expansin), three isoforms of group 12 (profilin) and three isoforms of group II allergens. In mature pollen, these three groups of allergens are the most abundant proteins. The comparison of proteome maps from different developmental stages demonstrated a very similar temporal expression pattern of these allergens during the anther development. The 
expression of $\beta$-expansin and profilin was first detected at the early or late binucleate stages and steadily increased to high levels at the pollen maturity. The expression of these proteins coincides with the formation of exine and intine wall layers and enlargement of pollen grains, indicating the involvement of these proteins in pollen cell wall structure and cell enlargement (discussed in Chapter 4).

Multiple isoforms of group II pollen allergens were identified in this study using a combination of proteomics and bioinformatics. As revealed by immunoblot analysis, their expression is specific to pollen, and they also displayed a temporal regulation pattern which is similar to $\beta$-expansins, implying their possible involvement in pollen development and fertilization processes. Until very recently, there was no report in scientific journals about the physiological function of group II pollen allergens. Li et al. very recently reported that the group 2 pollen allergens from ryegrass and timothy grass exhibited plant cell wall-loosening activity which is similar to $\beta$-expansins ( $\mathrm{Li}$ et al. 2003). They concluded that at least part of the characteristic cell wall-loosening action of $\beta$-expansin is attributable to its $\mathrm{C}$-terminal domain, which shares a high level of sequence homology with the corresponding group 2 allergens. Even if the cell expansion activity of the group II pollen allergens is confirmed, further research still needs to be done before the biological significance and exact molecular mechanism of redundant cell expansion activities of the group I and group II pollen allergens in plant reproductive development are elucidated.

\subsection{PRODUCTION OF POLYCLONAL ANTIBODIES USING A COMBINATION OF 2-DE AND NITROCELLULOSE BOUND ANTIGEN}

During the past few decades, immunocytochemical methods have become powerful and indispensable investigation tools for different aspects of plant science. The application of immunochemical methods in plant research often involves the production of monoclonal and polyclonal antibodies directed against some minor proteins, or against nonsoluble or membrane proteins, which are difficult to purify in native form by liquid-based fractionation approaches. In addition to its role as a differential display tool, the 2-DE has proved to be a quick and efficient method of obtaining pure antigenic material for immunization from crude or partially purified protein extracts (Diano and 
Bevic 1997). Once proteins are separated on 2-DE gels, the protein spots of interest can be excised from the lightly stained gels, ground and injected into animals with or without adjuvant. The generally poor results derived from this approach may be due to the toxicity of SDS and acrylamide in the antigen which cause intensive tissue and cell damage, resulting in the early death of the experimental animals (personal communication with Dr Nijat Imin, Australian National University, Canberra). As an alternative approach, the 2-DE separated proteins can be transferred to nitrocellulose membrane and the protein-bearing nitrocellulose is then solublized by physical or chemical means before being administrated to animals (Knudsen 1985). As demonstrated in Chapter 5, the antibody production to the 2-DE-purified Ory s 2 proteins was successful by this method using as little as $50 \mu \mathrm{g}$ proteins. The antibody production elicited to the low molecular weight proteins, without conjugation to carrier proteins, was probably partially attributable to the intrinsic allergenic nature of the Ory s 2 proteins. Another factor that contributed to the good immune response might be the adjuvant role of the nitrocellulose acting to slowly release the bound antigens, and thereby elicit a good immune response in animals.

The antibody production to 2-DE separated proteins in this study has demonstrated the parallel application of 2-DE based proteomics as a micropreparative tool in addition to its main application as a large-scale analytical approach. However, it should be kept in mind that the injection of a distinct protein spot does not necessarily result in the production of a mono-specific antibody as one protein spot on a gel can contain more than one protein population because some proteins with the similar $\mathrm{p} I$ and molecular weight can co-migrate to the same gel positions. As presented in Chapter 4 (Table 4.2), this is the case in two out of eight protein spots (25\%) which were subjected to $\mathrm{N}$ terminal sequencing. Therefore, special care should be taken while producing antibodies to 2-DE proteins identified by PMF analysis, because it is very difficult to confirm the homogeneity of the analyzed spots from the generated PMF data. Application of narrow range IPG strips in the micro- preparative 2-DE should increase the chance of obtaining homogenous antigens for antibody production.

\subsection{CONCLUSION AND FUTURE PERSPECTIVES}

This thesis has demonstrated the usefulness of 2-DE based proteomics for investigating the changing pattern of gene expression at the protein level during 
developmental processes in plants. In order to successfully follow a developmental sequence it is vital to have access to homogenous cell populations representing particular developmental stages. Otherwise, the real changes in protein expression levels will remain diluted or swamped by the overlapping or more abundant protein population. In this project, a considerable effort was made collect near homogenous anther populations by excluding the non-anther parts of the rice flower. This effort certainly resulted in the partial enrichment of some anther-specific and low abundant proteins.

An alternative method to collecting homogenous anther samples from rice flowers at different developmental stages is to subject the mixed microspore population to fractionation in a percoll or sucrose gradient (Fan, Armstrong et al. 1988). Although highly uniform microspore populations representing different developmental stages can be obtained in sufficient amounts, this method is not suitable for the isolation of premeiotic and early young microspores which lack of rigid pollen wall. As presented in Chapter 5, the isolation of mature pollen grains and the analysis of pollen proteins by 2DE have proven successful in our study. Unfortunately, a similar research approach has not been extended to the study of microspores from other stages due to the time limitation of the $\mathrm{PhD}$ project.

The development of methods for the isolation of generative cells, sperm cells, embryo sacs and egg cells from angiosperm plants has opened up new possibilities for plant reproductive research, utilizing proteomic and transcriptional profiling of generative or sperm cells. Viable sperm or generative cells can be isolated from the pollen grains or growing pollen tubes by enzymatic digestion, osmotic bursting or squashing, filtration and centrifugation (Matthysrochon et al. 1987; Theunis et al. 1991). In several plant species, the isolated sperm and generative cell has been subjected to transcriptional profiling, resulting in the identification of generative cell specific-genes and in the isolation of the male gametic cell-specific promoters (Singh et al. 2003; Xu, Swoboda et al. 1999b). McCormick's laboratory recently initiated a largescale project to construct and sequence cDNA libraries from isolated sperms, eggs, and embryo sacs of maize (for details visit http://www.pgec.usda.gov/McCormick/ McCormick/mclab.html). Similar studies have also been conducted at the protein level in Plumbago zeylanica L (Geltz and Russell 1988). The proteins extracted from sperm, cytoplasmic particulate and water-soluble fractions of mature pollen have been 
separated and compared. However, so far there is no report about the large-scale profiling of sperm or generative cell proteins in crop plants. Large-scale proteome profiling of isolated generative or sperm cells will provide a deeper insight into the protein composition of male gametophytes.

In parallel to proteomic profiling, it is also important to study the dynamic changes of gene expression during the male gametophyte development at the transcriptome level using large scale and high-throughput mRNA profiling techniques such as SAGE (serial analysis of gene expression) and DNA microarray analysis. This may enable the identification of some genes whose protein products are not displayed by 2-DE analysis. At the same time, the large-scale biochemical profiling approach, which is also known as metabolomics, can be applied to profile the changes of chemical constituents of male gamete cells at different developmental stages. This approach can complement the proteomic and transcriptomic analysis with functional data at the metabolome level.

It is hoped that in the new era of Systems Biology, technological improvements in proteomics and other global expression profiling tools will ultimately lead to the more complete unraveling of the molecular and biochemical mechanisms underlying male gametophyte developmental processes in crop plants. The knowledge derived from such studies can readily be exploited to resolve the practical problems such as cold- induced male sterility and self-incompatibility in plants, and will eventually contribute to the improvements of crop plants to the benefit of ever increasing world population. 


\section{REFERENCES}

Aebersold R, Mann M (2003) Mass spectrometry-based proteomics. Nature 422, 198207.

Aebersold RH, Leavitt J, Saavedra RA, Hood LE, Kent SB (1987) Internal amino acid sequence analysis of proteins separated by one- or two-dimensional gel electrophoresis after in situ protease digestion on nitrocellulose. Proc Natl Acad Sci U S A 84, 6970-6974.

Agrawal GK, Rakwal R, Yonekura M, Kubo A, Saji H (2002) Proteome analysis of differentially displayed proteins as a tool for investigating ozone stress in rice (Oryza sativa L.) seedlings. Proteomics 2, 947-959.

Albani D, Robert LS, Donaldson PA, Altosaar I, Arnison PG, Fabijanski SF (1990) Characterization of a pollen-specific gene family from Brassica napus which is activated during early microspore development. Plant Mol Biol 15, 605-622.

Altschul SF, Madden TL, Schaffer AA, Zhang J, Zhang Z, Miller W, Lipman DJ (1997) Gapped BLAST and PSI-BLAST: a new generation of protein database search programs. Nucleic Acids Res 25, 3389-3402.

Andersen JS, Mann M (2000) Functional genomics by mass spectrometry. FEBS Lett 480, 25-31.

Anderson L, Seilhamer J (1997) A comparison of selected mRNA and protein abundances in human liver. Electrophoresis 18, 533-537.

Anderson NG, Anderson L (1982) The Human Protein Index. Clin Chem 28, 739-748.

Anderson NL, Anderson NG (1998) Proteome and proteomics: new technologies, new concepts, and new words. Electrophoresis 19, 1853-1861.

Andersson K, Lidholm J (2003) Characteristics and immunobiology of grass pollen allergens. Int Arch Allergy Immunol 130, 87-107.

Andon NL, Eckert D, Yates JR, 3rd, Haynes PA (2003) High-throughput functional affinity purification of mannose binding proteins from Oryza sativa. Proteomics 3, 1270-1278.

Andon NL, Hollingworth S, Koller A, Greenland AJ,Yates JR., Haynes PA. (2002). Proteomic characterization of wheat amyloplasts using identification of proteins by tandem mass spectrometry. Proteomics 2, 1156-1168

Ansari AA, Freidhoff LR, Marsh DG (1989a) Molecular genetics of human immune responsiveness to Lolium perenne (rye) allergen, Lol p III. Int Arch Allergy Appl Immunol 88, 164-169. 
Ansari AA, Kihara TK, Marsh DG (1987) Immunochemical studies of Lolium perenne (rye grass) pollen allergens, Lol p I, II, and III. J Immunol 139, 40344041.

Ansari AA, Shenbagamurthi P, Marsh DG (1989b) Complete primary structure of a Lolium perenne (perennial rye grass) pollen allergen, Lol p III: comparison with known Lol p I and II sequences. Biochemistry 28, 8665-8670.

Ashcroft AE (2003) Protein and peptide identification: the role of mass spectrometry in proteomics. Nat Prod Rep 20, 202-215.

Asturias JA, Arilla MC, Gomezbayon N, Martinez J, Martinez A, Palacios R (1997) Cloning and high level expression of cynodon dactylon (bermuda grass) pollen profilin (cyn d 12) in escherichia coli - purification and characterization of the allergen. Clinical \& Experimental Allergy 27, 1307-1313.

Bae S, Cho J, Choi Y, Park K (2003). Analysis of the Arabidopsis nuclear proteome and its response to cold stress. Plant J 36(5): 652-663.

Bahrman N, Plomion C, Petit RJ, Kremer A (1997) CONTRIBUTION OF TWODIMENSIONAL ELECTROPHORESIS OF PROTEINS TO MARITIME PINE GENETICS [Review]. Annales des Sciences Forestieres 54, 225-236.

Baluska F, Salaj J, Mathur J, Braun M, Jasper F, Samaj J, Chua NH, Barlow PW, Volkmann D (2000) Root hair formation: F-actin-dependent tip growth is initiated by local assembly of profilin-supported F-actin meshworks accumulated within expansin-enriched bulges. Dev Biol 227, 618-632.

Bedinger P (1992) The remarkable biology of pollen. Plant Cell 4, 879-887.

Bedinger PA, Edgerton MD (1990) Developmental Staging of Maize Microspores Reveals a Transition in Developing Microspore Proteins. Plant Physiology 92, 474-479.

Bevan M, Murphy G (1999) The small, the large and the wild: the value of comparison in plant genomics. Trends Genet 15, 211-214.

Bjellqvist B, Ek K, Righetti PG, Gianazza E, Gorg A, Westermeier R, Postel W (1982) Isoelectric focusing in immobilized $\mathrm{pH}$ gradients: principle, methodology and some applications. J Biochem Biophys Methods 6, 317-339.

Blomstedt CK, Knox RB, Singh MB (1996) Generative cells of lilium longiflorum possess translatable mrna and functional protein synthesis machinery. Plant Molecular Biology 31, 1083-1086.

Blomstedt CK, Taylor PE, Singh MB, Knox RB (1997) The identification of an anther specific antigen in brassica species using a heterologous monoclonal antibody. Annals of Botany 80, 197-204. 
Bork P (2000) Powers and pitfalls in sequence analysis: the $70 \%$ hurdle. Genome Res 10, 398-400.

Bork P, Dandekar T, Diaz-Lazcoz Y, Eisenhaber F, Huynen M, Yuan Y (1998) Predicting function: from genes to genomes and back. J Mol Biol 283, 707-725.

Broadwater AH, RubinsteinAL, Chay CH, Klapper DG, Bedinger PA (1993) Zea $\mathrm{mI}$, the maize homolog of the allergen-encoding Lol pI gene of rye grass. Gene 131(2): 227-230.

Bufe A, Schramm G, Keown MB, Schlaak M, Becker WM (1995) Major allergen $\mathrm{Phl} \mathrm{p} \mathrm{Vb}$ in timothy grass is a novel pollen RNase. FEBS Lett 363, 6-12.

Chamovitz DA, Segal D (2001) JAB1/CSN5 and the COP9 signalosome. A complex situation. EMBO Rep 2, 96-101.

Chasan R, Walbot V (1993) Mechanisms of Plant Reproduction: Questions and Approaches. Plant Cell 5, 1139-1146.

Chaurand P, Luetzenkirchen F, Spengler B (1999) Peptide and protein identification by matrix-assisted laser desorption ionization (MALDI) and MALDI-postsource decay time-of-flight mass spectrometry. J Am Soc Mass Spectrom 10, 91103.

Chevallet M, Santoni V, Poinas A, Rouquie D, Fuchs A, Kieffer S, Rossignol M, Lunardi J, Garin J, Rabilloud T (1998) New zwitterionic detergents improve the analysis of membrane proteins by two-dimensional electrophoresis. Electrophoresis 19, 1901-1909.

Chivasa S, Ndimba K, Simon W J, Robertson D, Yu XL, Knox JP, Bolwell P, Slabas AR (2002). Proteomic analysis of the Arabidopsis thaliana cell wall. Electrophoresis 23(11): 1754-65.

Cho HT, Kende H (1998) Tissue localization of expansins in deepwater rice. Plant Journal 15, 805-812.

Chung YY, Kim SR, Kang HG, Noh YS, Park MC, Finkel D, An GH (1995) Characterization of two rice mads box genes homologous to globosa. Plant Science 109, 45-56.

Clarke SR, Staiger CJ, Gibbon BC, Franklin-Tong VE (1998) A potential signaling role for profilin in pollen of Papaver rhoeas. Plant Cell 10, 967-979.

Cordewener J, Bergervoet J, Liu CM (2000) Changes in protein synthesis and phosphorylation during microspore embryogenesis in Brassica napus. Journal of Plant Physiology 156, 156-163.

Cordewener JHG, Busink R, Traas JA, Custers JBM, Dons HJM, Campagne MMV (1994) Induction of microspore embryogenesis in brassica napus 1 is accompanied by specific changes in protein synthesis. Planta 195, 50-56. 
Cordwell SJ, Nouwens AS, Verrills NM, Basseal DJ, Walsh BJ (2000) Subproteomics based upon protein cellular location and relative solubilities in conjunction with composite two-dimensional electrophoresis gels. Electrophoresis 21, 1094-1103.

Cosgrove DJ (1997) Creeping walls, softening fruit, and penetrating pollen tubes - the growing roles of expansins. Proceedings of the National Academy of Sciences of the United States of America 94, 5504-5505.

Cosgrove DJ (2000) Loosening of plant cell walls by expansins [Review]. Nature 407, 321-326.

Cosgrove DJ, Bedinger P, Durachko DM (1997) Group i allergens of grass pollen as cell wall-loosening agents. Proceedings of the National Academy of Sciences of the United States of America 94, 6559-6564.

Cozzone AJ (1998) Post-translational modification of proteins by reversible phosphorylation in prokaryotes. Biochimie 80, 43-48.

Damerval C, Ziv M, Granier F, de Vienne D (1988) Two dimensional electrophoresis in plant biology. In 'Advances in Electrophoresis'. (Eds A Chrambach, MJ Dunn and BJ Radola) pp. 263-340. (VCH: Weinheim, Germany)

de Saizieu A, Certa U, Warrington J, Gray C, Keck W, Mous J (1998) Bacterial transcript imaging by hybridization of total RNA to oligonucleotide arrays. Nat Biotechnol 16, 45-48.

Delseny M (2003) Towards an accurate sequence of the rice genome. Curr Opin Plant Biol 6, 101-105.

Deng XW, Dubiel W, Wei N, Hofmann K, Mundt K (2000) Unified nomenclature for the COP9 signalosome and its subunits: an essential regulator of development. Trends Genet 16, 289.

Diano M, Bevic A (1997) Production of Highly Specific Polyclonal Antibodies Using a Combination of 2D Electrophoresis and Nitrocellulose-Bound Antigen. In 'The Protein Protocols Handbook'. (Ed. JM Walker) pp. 703-710. (Humana Press: Totowa, NJ)

Dolecek C, Vrtala S, Laffer S, Steinberger P, Kraft D, Scheiner O, Valenta R (1993) Molecular characterization of Phl p II, a major timothy grass (Phleum pratense) pollen allergen. FEBS Lett 335, 299-304.

Drenckhahn D, Jons T, Schmitz F (1993) Production of polyclonal antibodies against proteins and peptides. Methods Cell Biol 37, 7-56.

Dubey H, Grover A (2001) Current initiatives in proteomics research: The plant perspective. Current Science 80, 262-269.

Edman P (1949) A method for the determination of the amino acid sequence of peptides. Arch Biochem Biophys 22, 475-483. 
Edman P, Begg G (1967) A protein sequenator. Eur J Biochem 1, 80-91.

Eisen MB, Brown PO (1999) DNA arrays for analysis of gene expression. Methods Enzymol 303, 179-205.

Eisenstein E, Gilliland GL, Herzberg O, Moult J, Orban J, Poljak RJ, Banerjei L, Richardson D, Howard AJ (2000) Biological function made crystal clear annotation of hypothetical proteins via structural genomics [Review]. Current Opinion in Biotechnology 11, 25-30.

Erickson RO (1948) Cytological and growth correlations in the flower bud and anther of Lilium longiflorum. American Journal of Botany 35, 729-739.

Fan Z, Armstrong KC, Keller WA (1988) Development of Microspores Invivo and Invitro in Brassica-Napus L. Protoplasma 147, 191-199.

Faure JE, Digonnet C, Dumas C (1994) An in vitro system for adhesion and fusion of maize gametes. Science 263, 1598-1600.

Fenn JB, Mann M, Meng CK, Wong SF, Whitehouse CM (1989) Electrospray ionization for mass spectrometry of large biomolecules. Science 246, 64-71.

Ferrari BC, Attfield PV, Veal DA, Bell PJ (2003) Application of the novel fluorescent dye Beljian red to the differentiation of Giardia cysts. $J$ Microbiol Methods 52, 133-135.

Freidhoff LR, Ehrlich-Kautzky E, Grant JH, Meyers DA, Marsh DG (1986) A study of the human immune response to Lolium perenne (rye) pollen and its components, Lol p I and Lol p II (rye I and rye II). I. Prevalence of reactivity to the allergens and correlations among skin test, IgE antibody, and IgG antibody data. J Allergy Clin Immunol 78, 1190-1201.

Fu H, Girod PA, Doelling JH, van Nocker S, Hochstrasser M, Finley D, Vierstra RD (1999) Structure and functional analysis of the 26S proteasome subunits from plants. Mol Biol Rep 26, 137-146.

Gale MD, Devos KM (1998) Comparative genetics in the grasses. Proc Natl Acad Sci US A 95, 1971-1974.

Garrels JI, McLaughlin CS, Warner JR, Futcher B, Latter GI, Kobayashi R, Schwender B, Volpe T, Anderson DS, Mesquita-Fuentes R, Payne WE (1997) Proteome studies of Saccharomyces cerevisiae: identification and characterization of abundant proteins. Electrophoresis 18, 1347-1360.

Gasser CS (1991) Molecular studies on the differentiation of floral organs. Annual Review of Plant Physiology and Plant Molecular Biology 42, 621-649. 
Geltz NR, Russell SD (1988) Two-Dimensional Electrophoretic Studies of the Proteins and Polypeptides in Mature Pollen Grains and the Male Germ Unit of Plumbago-Zeylanica. Plant Physiology 88, 764-769.

Gevaert K, Vandekerckhove J (2000) Protein identification methods in proteomics. Electrophoresis 21, 1145-1154.

Gharahdaghi F, Weinberg CR, Meagher DA, Imai BS, Mische SM (1999) Mass spectrometric identification of proteins from silver-stained polyacrylamide gel: a method for the removal of silver ions to enhance sensitivity. Electrophoresis 20, 601-605.

Goff SA (1999) Rice as a model for cereal genomics. Curr Opin Plant Biol 2, 86-89.

Goff SA, Ricke D, Lan TH, Presting G, Wang R, Dunn M, Glazebrook J, Sessions A, Oeller P, Varma H, Hadley D, Hutchison D, Martin C, Katagiri F, Lange BM, Moughamer T, Xia Y, Budworth P, Zhong J, Miguel T, Paszkowski U, Zhang S, Colbert M, Sun WL, Chen L, Cooper B, Park S, Wood TC, Mao L, Quail P, Wing R, Dean R, Yu Y, Zharkikh A, Shen R, Sahasrabudhe S, Thomas A, Cannings R, Gutin A, Pruss D, Reid J, Tavtigian S, Mitchell J, Eldredge G, Scholl T, Miller RM, Bhatnagar S, Adey N, Rubano T, Tusneem N, Robinson R, Feldhaus J, Macalma T, Oliphant A, Briggs S (2002) A draft sequence of the rice genome (Oryza sativa L. ssp. japonica). Science 296, 92-100.

Goldberg RB (1988) Plants: novel developmental processes. Science 240, 1460-1467.

Gonzalez F, Delahodde A, Kodadek T, Johnston SA (2002) Recruitment of a 19S proteasome subcomplex to an activated promoter. Science 296, 548-550.

Gorg A, Boguth G, Obermaier C, Posch A, Weiss W (1995) Two-dimensional polyacrylamide gel electrophoresis with immobilized $\mathrm{pH}$ gradients in the first dimension (IPG-Dalt): the state of the art and the controversy of vertical versus horizontal systems. Electrophoresis 16, 1079-1086.

Gorg A, Obermaier C, Boguth G, Harder A, Scheibe B, Wildgruber R, Weiss W (2000) The current state of two-dimensional electrophoresis with immobilized pH gradients. Electrophoresis 21, 1037-1053.

Gorg A, Postel W, Gunther S (1988) The current state of two-dimensional electrophoresis with immobilized pH gradients. Electrophoresis 9, 531-546.

Gould KS, Lord EM (1988) Growth of Anthers in Lilium-Longiflorum - a Kinematic Analysis. Planta 173, 161-171.

Griffith IJ, Smith PM, Pollock J, Theerakulpisut P, Avjioglu A, Davies S, Hough T, Singh MB, Simpson RJ, Ward LD, et al. (1991) Cloning and sequencing of Lol pI, the major allergenic protein of rye- grass pollen. FEBS Lett 279, 210215. 
Grobe K, Becker WM, Schlaak M, Petersen A (1999) Grass group I allergens (betaexpansins) are novel, papain-related proteinases. Eur J Biochem 263, 33-40.

Grobe K, Poppelmann M, Becker WM, Petersen A (2002) Properties of group I allergens from grass pollen and their relation to cathepsin $\mathrm{B}$, a member of the $\mathrm{C} 1$ family of cysteine proteinases. Eur J Biochem 269, 2083-2092.

Guerreiro N, Redmond JW, Rolfe BG, Djordjevic MA (1997) New Rhizobium leguminosarum flavonoid-induced proteins revealed by proteome analysis of differentially displayed proteins. Mol Plant Microbe Interact 10, 506-516.

Gygi SP, Aebersold R (2000) Mass spectrometry and proteomics [In Process Citation]. Curr Opin Chem Biol 4, 489-494.

Gygi SP, Corthals GL, Zhang Y, Rochon Y, Aebersold R (2000) Evaluation of twodimensional gel electrophoresis-based proteome analysis technology. Proc Natl Acad Sci U S A 97, 9390-9395.

Gygi SP, Rist B, Gerber SA, Turecek F, Gelb MH, Aebersold R (1999a) Quantitative analysis of complex protein mixtures using isotope-coded affinity tags. Nat Biotechnol 17, 994-999.

Gygi SP, Rochon Y, Franza BR, Aebersold R (1999b) Correlation between protein and mRNA abundance in yeast. Mol Cell Biol 19, 1720-1730.

Hajduch M, Rakwal R, Agrawal GK, Yonekura M, Pretova A (2001) Highresolution two-dimensional electrophoresis separation of proteins from metalstressed rice (Oryza sativa L.) leaves: drastic reductions/fragmentation of ribulose-1,5-bisphosphate carboxylase/oxygenase and induction of stress-related proteins. Electrophoresis 22, 2824-2831.

Hanson DD, Hamilton DA, Travis JL, Bashe DM, Mascarenhas JP (1989) Characterization of a pollen-specific cDNA clone from Zea mays and its expression. Plant Cell 1, 173-179.

Harry JL, Wilkins MR, Herbert BR, Packer NH, Gooley AA, Williams KL (2000) Proteomics: capacity versus utility. Electrophoresis 21, 1071-1081.

Haynes PA, Gygi SP, Figeys D, Aebersold R (1998) Proteome analysis: biological assay or data archive? Electrophoresis 19, 1862-1871.

Haynes PA, Yates JR, 3rd (2000) Proteome profiling-pitfalls and progress. Yeast 17, 81-87.

Heazlewood JL, Howell KA, Whelan J, Millar AH (2003) Towards an analysis of the rice mitochondrial proteome. Plant Physiol 132, 230-242.

Hellmann H, Estelle M (2002) Plant development: regulation by protein degradation. Science 297, 793-797. 
Henzel WJ, Billeci TM, Stults JT, Wong SC, Grimley C, Watanabe C (1993) Identifying proteins from two-dimensional gels by molecular mass searching of peptide fragments in protein sequence databases. Proc Natl Acad Sci USA 90, 5011-5015.

Herbert B (1999) Advances in protein solubilisation for two-dimensional electrophoresis. Electrophoresis 20, 660-663.

Herbert BR, Harry JL, Packer NH, Gooley AA, Pedersen SK, Williams KL (2001) What place for polyacrylamide in proteomics? Trends Biotechnol 19, S3-9.

Herskovits TT, Jaillet H, Gadegbeku B (1970) On the structural stability and solvent denaturation of proteins. II. Denaturation by the ureas. J Biol Chem 245, 45444550 .

Hewick RM, Hunkapiller MW, Hood LE, Dreyer WJ (1981) A gas-liquid solid phase peptide and protein sequenator. J Biol Chem 256, 7990-7997.

Hieter P, Boguski M (1997) Functional genomics: it's all how you read it. Science 278, 601-602.

Hihara Y, Hara C, Uchimiya H (1996) Isolation and characterization of two cdna clones for mrnas that are abundantly expressed in immature anthers of rice (oryza sativa 1.). Plant Molecular Biology 30, 1181-1193.

Hird DL, Worrall D, Hodge R, Smartt S, Paul W, Scott R (1993) The anther-specific protein encoded by the Brassica napus and Arabidopsis thaliana A6 gene displays similarity to beta-1,3-glucanases. Plant J 4, 1023-1033.

Holtorf H, Guitton MC, Reski R (2002) Plant functional genomics. Naturwissenschaften 89, 235-249.

Hood L (2003) Systems biology: integrating technology, biology, and computation. Mech Ageing Dev 124, 9-16.

Horgan GW, Glasbey CA (1995) Uses of digital image analysis in electrophoresis. Electrophoresis 16, 298-305.

Huber LA (2003) Is proteomics heading in the wrong direction? Nat Rev Mol Cell Biol 4, 74-80.

Imin N (2002) Molecular mechanisms causing cold induced male sterility in rice: A proteomic investigation. $\mathrm{PhD}$ thesis, Australian national University.

Imin N, Kerim T, Weinman JJ, Rolfe BG (2001) Characterisation of rice anther proteins expressed at the young microspore stage. Proteomics 1, 1149-1161.

Izawa T, Shimamoto K (1996) Becoming a model plant - the importance of rice to plant science. Trends in Plant Science 1, 95-99. 
Jacobs DI, van der Heijden R, Verpoorte R (2000) Proteomics in plant biotechnology and secondary metabolism research. Phytochemical Analysis 11, 277-287.

Jeffery CJ (1999) Moonlighting proteins. Trends in Biochemical Sciences 24, 8-11.

Jeffery CJ (2003) Moonlighting proteins: old proteins learning new tricks. Trends in Genetics 19, 415-417.

Jensen ON, Wilm M, Shevchenko A, Mann M (1999) Peptide sequencing of 2-DE gel-isolated proteins by nanoelectrospray tandem mass spectrometry. Methods Mol Biol 112, 571-588.

Jeon JS, Chung YY, Lee S, Yi GH, Oh BG, An GH (1999) Isolation and characterization of an anther-specific gene, RA8, from rice (Oryza sativa L.). Plant Molecular Biology 39, 35-44.

Jong K (1997) 'Laboratory manual of plant cytological techniques.' ( Royal Botanic Garden Edinburgh: Edinburgh)

Kalinowski A, Winiarczyk K, Radlowski M (2002) Pollen coat proteins after twodimensional gel electrophoresis and pollen wall ultrastructure of Secale cereale and Festuca pratensis. Sex Plant Reprod 15, 75-83.

Kalinowski A, Winiarczyk K, Wojciechowska B (2001) Pollen proteins after twodimensional gel electrophoresis and pollen morphology of the amphiploids Aegilops kotschyi and Ae. variabilis with Secale cereale. Sexual Plant Reproduction 14, 153-161.

Kamalay JC, Goldberg RB (1980) Regulation of structural gene expression in tobacco. Cell 19, 935-946.

Kamalay JC, Goldberg RB (1984) Organ-specific nuclear RNAs in tobacco. Proc Natl Acad Sci U S A 81, 2801-2805.

Kamo M, Kawakami T, Miyatake N, Tsugita A (1995) Separation and characterization of Arabidopsis thaliana proteins by two- dimensional gel electrophoresis. Electrophoresis 16, 423-430.

Kang HG, Jang S, Chung JE, Cho YG, An G (1997) Characterization of two rice MADS box genes that control flowering time. Mol Cells 7, 559-566.

Karas M, Hillenkamp F (1988) Laser desorption ionization of proteins with molecular masses exceeding 10,000 daltons. Anal Chem 60, 2299-2301.

Karniol B, Chamovitz DA (2000) The COP9 signalosome: from light signaling to general developmental regulation and back. Curr Opin Plant Biol 3, 387-393.

Kaul S, Koo HL, Jenkins J, Rizzo M, Rooney T, Tallon LJ, Feldblyum T, Nierman W, Benito MI, Lin XY, Town CD, Venter JC, Fraser CM, Tabata S, Nakamura Y, Kaneko T, Sato S, Asamizu E, Kato T, Kotani H, Sasamoto S, Ecker JR, Theologis A, Federspiel NA, Palm CJ, et al. (2000) Analysis of the 
genome sequence of the flowering plant Arabidopsis thaliana [Review]. Item Corporate Author Arabidopsis Genome Initiative 408, 796-815.

Kersten B, Burkle L, Kuhn EJ, Giavalisco P, Konthur Z, Lueking A, Walter G, Eickhoff H, Schneider U (2002) Large-scale plant proteomics. Plant Mol Biol 48, 133-141.

Kikuchi S, Satoh K, Nagata T, Kawagashira N, Doi K, Kishimoto N, Yazaki J, Ishikawa M, Yamada H, Ooka H, Hotta I, Kojima K, Namiki T, Ohneda E, Yahagi W, Suzuki K, Li CJ, Ohtsuki K, Shishiki T, Otomo Y, Murakami K, Iida Y, Sugano S, Fujimura T, Suzuki Y, Tsunoda Y, Kurosaki T, Kodama T, Masuda H, Kobayashi M, Xie Q, Lu M, Narikawa R, Sugiyama A, Mizuno K, Yokomizo S, Niikura J, Ikeda R, Ishibiki J, Kawamata M, Yoshimura A, Miura J, Kusumegi T, Oka M, Ryu R, Ueda M, Matsubara K, Kawai J, Carninci P, Adachi J, Aizawa K, Arakawa T, Fukuda S, Hara A, Hashidume W, Hayatsu N, Imotani K, Ishii Y, Itoh M, Kagawa I, Kondo S, Konno H, Miyazaki A, Osato N, Ota Y, Saito R, Sasaki D, Sato K, Shibata K, Shinagawa A, Shiraki T, Yoshino M, Hayashizaki Y (2003) Collection, mapping, and annotation of over $28,000 \mathrm{cDNA}$ clones from japonica rice. Science 301, 376-379.

Kimura T, Todokoro M, Kuroume T, Tatemo K, Matsumura T (1969) Rice pollen asthma. II. Cross antigenicity between rice pollen and other grass pollens. Arerugi 18, 1005-1016.

King TP, Hoffman D, Lowenstein H, Marsh DG, Platts-Mills TA, Thomas W (1994) Allergen nomenclature. WHO/IUIS Allergen Nomenclature Subcommittee. Int Arch Allergy Immunol 105, 224-233.

Klose J (1975) Protein mapping by combined isoelectric focusing and electrophoresis of mouse tissues. A novel approach to testing for induced point mutations in mammals. Humangenetik 26, 231-243.

Klose J, Kobalz U (1995) Two-dimensional electrophoresis of proteins: an updated protocol and implications for a functional analysis of the genome. Electrophoresis 16, 1034-1059.

Knox RB, Zee SY, Blomstedt C, Singh MB (1993) MALE GAMETES AND FERTILIZATION IN ANGIOSPERMS [Review]. New Phytologist 125, 679694.

Knudsen KA (1985) Proteins transferred to nitrocellulose for use as immunogens. Anal Biochem 147, 285-288.

Kobayashi T, Kobayashi E, Sato S, Hotta Y, Miyajima N, Tanaka A, Tabata S (1994) Characterization of cDNAs induced in meiotic prophase in lily microsporocytes. DNA Res 1, 15-26.

Koller A, Washburn MP, Lange BM, Andon NL, Deciu C, Haynes PA, Hays L, Schieltz D, Ulaszek R, Wei J, Wolters D, Yates JR, 3rd (2002) From the 
Cover: Proteomic survey of metabolic pathways in rice. Proc Natl Acad Sci US A 99, 11969-11974.

Koltunow AM (1990) Different Temporal anad Spatial Gene expression Patterns occur during Anther Development. The Plant Cell 2, 1201-1224.

Komatsu S, Kajiwara H, Hirano H (1993) A rice protein library - a data-file of rice proteins separated by 2-dimensional electrophoresis. Theoretical \& Applied Genetics 86, 935-942.

Kovar DR, Drobak BK, Staiger CJ (2000) Maize profilin isoforms are functionally distinct. Plant Cell 12, 583-598.

Kowyama Y, Saba T, Tsuji T, Kawase T (1994) Specific developmental stages of gametogenesis for radiosensitivity and mutagenesis in rice. Euphytica 80, 27-38.

Kranz E, Dresselhaus T (1996) IN VITRO FERTILIZATION WITH ISOLATED HIGHER PLANT GAMETES [Review]. Trends in Plant Science 1, 82-89.

Kranz E, Lorz H (1993) In Vitro Fertilization with Isolated, Single Gametes Results in Zygotic Embryogenesis and Fertile Maize Plants. Plant Cell 5, 739-746.

Kurland CG (1991) Codon bias and gene expression. FEBS Lett 285, 165-169.

Lay Jr. JO, Holland RD (2000) Rapid identification of bacteria based on spectral patterns using MALDI-TOF MS. In 'Methods in Molecular Biology'. (Ed. JR Chapman) pp. 461-487. (Humana Press: Totowa, New Jersey)

Lemkin PF (1997) Comparing two-dimensional electrophoretic gel images across the Internet. Electrophoresis 18, 461-470.

Li LC, Cosgrove DJ (2001) Grass group I pollen allergens (beta-expansins) lack proteinase activity and do not cause wall loosening via proteolysis. Eur $J$ Biochem 268, 4217-4226.

Li L-C, Shieh MW, Cosgrove DJ (2003) Group 2 and group 3 allergens of grass pollen have plant cell wall-loosening activity characteristic of b-expansins. In 'American Society of Plant Biologists'. Honolulu, Hawaii USA

Liebler CD (2002) 'Introduction to proteomics: Tools for the new biology.' (Humana Press: Totowa, NJ)

Lifschitz E (1988) Molecular markers for the floral program. Flowering Newsl 6, 1620.

Link AJ, Eng J, Schieltz DM, Carmack E, Mize GJ, Morris DR, Garvik BM, Yates JR, 3rd (1999) Direct analysis of protein complexes using mass spectrometry. Nat Biotechnol 17, 676-682.

Lockhart DJ, Winzeler EA (2000) Genomics, gene expression and DNA arrays. Nature 405, 827-836. 
Lopez MF, Berggren K, Chernokalskaya E, Lazarev A, Robinson M, Patton WF (2000) A comparison of silver stain and SYPRO Ruby Protein Gel Stain with respect to protein detection in two-dimensional gels and identification by peptide mass profiling. Electrophoresis 21, 3673-3683.

Mann M, Hendrickson RC, Pandey A (2001) Analysis of proteins and proteomes by mass spectrometry. Annu Rev Biochem 70, 437-473.

Mann M, Jensen ON (2003) Proteomic analysis of post-translational modifications. Nat Biotechnol 21, 255-261.

Mann M, Ong SE, Gronborg M, Steen H, Jensen ON, Pandey A (2002) Analysis of protein phosphorylation using mass spectrometry: deciphering the phosphoproteome. Trends Biotechnol 20, 261-268.

Mann M, Pandey A (2001) Use of mass spectrometry-derived data to annotate nucleotide and protein sequence databases. Trends Biochem Sci 26, 54-61.

Mann M, Wilm M (1994) Error-tolerant identification of peptides in sequence databases by peptide sequence tags. Anal Chem 66, 4390-4399.

Marknell DeWitt A, Niederberger V, Lehtonen P, Spitzauer S, Sperr WR, Valent P, Valenta R, Lidholm J (2002) Molecular and immunological characterization of a novel timothy grass (Phleum pratense) pollen allergen, Phl p 11. Clin Exp Allergy 32, 1329-1340.

Martin SE, Shabanowitz J, Hunt DF, Marto JA (2000) Subfemtomole MS and MS/MS peptide sequence analysis using nano-HPLC micro-ESI fourier transform ion cyclotron resonance mass spectrometry. Anal Chem 72, 42664274.

Mascarenhas JP (1990) Gene activity during pollen development. . Annual review of Plant Physiology and Plant Molecular biology 41, 317-338.

Mathesius U, Imin N, Chen H, Djordjevic MA, Weinman JJ, Natera SH, Morris AC, Kerim T, Paul S, Menzel C, Weiller GF, Rolfe BG (2002) Evaluation of proteome reference maps for cross-species identification of proteins by peptide mass fingerprinting. Proteomics 2, 1288-1303.

Mathesius U, Keijzers G, Natera SH, Weinman JJ, Djordjevic MA, Rolfe BG (2001) Establishment of a root proteome reference map for the model legume Medicago truncatula using the expressed sequence tag database for peptide mass fingerprinting. Proteomics 1, 1424-1440.

Matsudaira P (1987) Sequence from picomole quantities of proteins electroblotted onto polyvinylidene difluoride membranes. J Biol Chem 262, 10035-10038.

Matsumura T, Kimura T, Tatemo K, Kato E, Todokoro M, Nakajima S, Kuroume T (1969) Rice pollen asthma. Journal of Asthma Research 7, 7-16. 
Matsuo T, Hoshikawa K. (1993) 'Science of the Rice Plant.' (Food and Agriculture Policy Recearch Center, Tokyo)

Matsushima V, Manaka T (1956) Developmental process of the young panicle of rice and its diagnosis in rice plants, developmental process of young panicles in all stems, its standard and characteristics of each developmental stages. Assoc Agric. Technol., Tokyo, , 1-58.

Matthysrochon E, Vergne P, Detchepare S, Dumas C (1987) Male Germ Unit Isolation from 3 Tricellular Pollen Species - Brassica-Oleracea, Zea-Mays, and Triticum-Aestivum. Plant Physiology 83, 464-466.

Mayfield JA, Fiebig A, Johnstone SE, Preuss D (2001) Gene families from the Arabidopsis thaliana pollen coat proteome. Science 292, 2482-2485.

McCormack AL, Schieltz DM, Goode B, Yang S, Barnes G, Drubin D, Yates JR, 3rd (1997) Direct analysis and identification of proteins in mixtures by LC/MS/MS and database searching at the low-femtomole level. Anal Chem 69, 767-776.

McCormick S (1993) Male Gametophyte Development. Plant Cell 5, 1265-1275.

McCurdy DW, Kovar DR, Staiger CJ (2001) Actin and actin-binding proteins in higher plants. Protoplasma 215, 89-104.

Medzihradszky KF, Campbell JM, Baldwin MA, Falick AM, Juhasz P, Vestal ML, Burlingame AL (2000) The characteristics of peptide collision-induced dissociation using a high-performance MALDI-TOF/TOF tandem mass spectrometer. Anal Chem 72, 552-558.

Molloy MP, Herbert BR, Williams KL, Gooley AA (1999) Extraction of Escherichia coli proteins with organic solvents prior to two-dimensional electrophoresis. Electrophoresis 20, 701-704.

Moons A, Prinsen E, Bauw G, Van Montagu M (1997) Antagonistic effects of abscisic acid and jasmonates on salt stress-inducible transcripts in rice roots. Plant Cell 9, 2243-2259.

Mori T, Tanaka I (2000) Isolation of the ftsZ gene from plastid-deficient generative cells of Lilium longiflorum. Protoplasma 214, 57-64.

Mortz E, Krogh TN, Vorum H, Gorg A (2001) Improved silver staining protocols for high sensitivity protein identification using matrix-assisted laser desorption/ionization-time of flight analysis. Proteomics 1, 1359-1363.

Munchbach M, Quadroni M, Miotto G, James P (2000) Quantitation and facilitated de novo sequencing of proteins by isotopic N-terminal labeling of peptides with a fragmentation-directing moiety. Anal Chem 72, 4047-4057. 
Natera SH, Guerreiro N, Djordjevic MA (2000) Proteome analysis of differentially displayed proteins as a tool for the investigation of symbiosis. Mol Plant Microbe Interact 13, 995-1009.

Nelson DL, Cox MM (2000) 'Princples of Biochemistry.' (Worth Publishers: New York)

Neuhoff V, Arold N, Taube D, Ehrhardt W (1988) Improved staining of proteins in polyacrylamide gels including isoelectric focusing gels with clear background at nanogram sensitivity using Coomassie Brilliant Blue G-250 and R-250. Electrophoresis 9, 255-262.

Nguyen-Quoc B, Foyer CH (2001) A role for 'futile cycles' involving invertase and sucrose synthase in sucrose metabolism of tomato fruit. $J$ Exp Bot 52, 881-889.

Nielsen H, Engelbrecht J, Brunak S, von Heijne G (1997) Identification of prokaryotic and eukaryotic signal peptides and prediction of their cleavage sites. Protein Eng 10, 1-6.

Nishiyama I (1982) Male sterility caused by cooling treatment at the young microspore stage in rice plants. Japanese Journal of Crop Science 51, 462-469.

O'Farrell PH (1975) High resolution two-dimensional electrophoresis of proteins. $J$ Biol Chem 250, 4007-4021.

Oldenhof MT, de Groot PF, Visser JH, Schrauwen JA, Wullems GJ (1996) Isolation and characterization of a microspore-specific gene from tobacco. Plant Mol Biol 31, 213-225.

Ong SE, Blagoev B, Kratchmarova I, Kristensen DB, Steen H, Pandey A, Mann M (2002) Stable isotope labeling by amino acids in cell culture, SILAC, as a simple and accurate approach to expression proteomics. Mol Cell Proteomics 1, 376386.

Ong SE, Pandey A (2001) An evaluation of the use of two-dimensional gel electrophoresis in proteomics. Biomol Eng 18, 195-205.

Pandey A, Lewitter F (1999) Nucleotide sequence databases: a gold mine for biologists. Trends Biochem Sci 24, 276-280.

Pandey A, Mann M (2000) Proteomics to study genes and genomes. Nature 405, 837846.

Patton WF (2002) Detection technologies in proteome analysis. $J$ Chromatogr $B$ Analyt Technol Biomed Life Sci 771, 3-31.

Pearson WR, Lipman DJ (1988) Improved tools for biological sequence comparison. Proc Natl Acad Sci U S A 85, 2444-2448. 
Piatigorsky J (1998) Multifunctional lens crystallins and corneal enzymes. More than meets the eye. Ann N Y Acad Sci 842, 7-15.

Porubleva L, Vander Velden K, Kothari S, Oliver DJ, Chitnis PR (2001) The proteome of maize leaves: use of gene sequences and expressed sequence tag data for identification of proteins with peptide mass fingerprints. Electrophoresis 22, 1724-1738.

Quadroni M, James P (1999) Proteomics and automation. Electrophoresis 20, 664677.

Rabilloud T (1999) Solubilization of proteins in 2-D electrophoresis. In '2-D Proteome Analysis Protocols'. (Ed. AJ Link) pp. 9-19. (Humana press: Totowa)

Rabilloud T, Vuillard L, Gilly C, Lawrence JJ (1994) Silver-staining of proteins in polyacrylamide gels: a general overview. Cell Mol Biol (Noisy-le-grand) 40, 5775.

Raghavan V (1988) Anther and Pollen Development in Rice (Oryza Sativa). American Journal of Botany 75, 183-196.

Raikhel NV, Coruzzi GM (2003) Plant systems biology. Plant Physiol 132, 403.

Rakwal R, Agrawal GK, Kubo A, Yonekura M, Tamogami S, Saji H, Iwahashi H (2003) Defense/stress responses elicited in rice seedlings exposed to the gaseous air pollutant sulfur dioxide. Environmental and Experimental Botany 49, 223235 .

Rakwal R, Agrawal GK, Yonekura M (1999) Separation of proteins from stressed rice (Oryza sativa L.) leaf tissues by two-dimensional polyacrylamide gel electrophoresis: induction of pathogenesis-related and cellular protectant proteins by jasmonic acid, UV irradiation and copper chloride. Electrophoresis 20, 3472-3478.

Rakwal R, Komatsu S (2000) Role of jasmonate in the rice (Oryza sativa L.) selfdefense mechanism using proteome analysis [In Process Citation]. Electrophoresis 21, 2492-2500.

Ramachandran S, Christensen HE, Ishimaru Y, Dong CH, Chao-Ming W, Cleary AL, Chua NH (2000) Profilin plays a role in cell elongation, cell shape maintenance, and flowering in arabidopsis. Plant Physiol 124, 1637-1647.

Raven PH, Evert RF, Eichhorn SE (1992) 'Biology of Plants.' (Worth Publishers: New York)

Rigaut G, Shevchenko A, Rutz B, Wilm M, Mann M, Seraphin B (1999) A generic protein purification method for protein complex characterization and proteome exploration. Nat Biotechnol 17, 1030-1032. 
Righetti PG, Macelloni C (1982) New polyacrylamide matrices for drift-free isoelectric focusing. J Biochem Biophys Methods 6, 1-15.

Roberts AM, Bevan LJ, Flora PS, Jepson I, Walker MR (1993a) Nucleotide sequence of cDNA encoding the group II allergen of cocksfoot/orchard grass (Dactylis glomerata), Dac g II. Allergy 48, 615-623.

Roberts JK (2002) Proteomics and a future generation of plant molecular biologists. Plant Mol Biol 48, 143-154.

Roberts MR, Foster GD, Blundell RP, Robinson SW, Kumar A, Draper J, Scott R (1993b) Gametophytic and sporophytic expression of an anther-specific Arabidopsis thaliana gene. Plant J 3, 111-120.

Rogers HJ, Maund SL, Johnson LH (2001) A beta-galactosidase-like gene is expressed during tobacco pollen development. J Exp Bot 52, 67-75.

Rossignol M (2001) Analysis of the plant proteome. Curr Opin Biotechnol 12, 131-134.

Salekdeh GH, Siopongco J, Wade LJ, Ghareyazie B, Bennett J (2002a) Proteomic analysis of rice leaves during drought stress and recovery. Proteomics 2, 11311145.

Salekdeh GH, Siopongco J, Wade LJ, Ghareyazie B, Bennett J (2002b) A proteomic approach to analyzing drought- and salt-responsiveness in rice. Field Crops Research 76, 199-219.

Salse J, Piegu B, Cooke R, Delseny M (2002) Synteny between Arabidopsis thaliana and rice at the genome level: a tool to identify conservation in the ongoing rice genome sequencing project. Nucleic Acids Res 30, 2316-2328.

Santoni V, Molloy M, Rabilloud T (2000) Membrane proteins and proteomics: un amour impossible? Electrophoresis 21, 1054-1070.

Sasaki T, Burr B (2000) International Rice Genome Sequencing Project: the effort to completely sequence the rice genome. Curr Opin Plant Biol 3, 138-141.

Satake T, Hayase H (1970) Proc.CropSci.Soc. Jpn. 39, 468-473.

Schrauwen J, de Groot PF, van Herpen M, van der Lee T, Reynen WH, Weterings K, Wullems G (1990) Stage-related expression of mRNAs during pollen development in lily and tobacco. Planta 182, 298-304.

Scott R, Dagless E, Hodge R, Paul W, Soufleri I, Draper J (1991) Patterns of gene expression in developing anthers of Brassica napus. Plant Mol Biol 17, 195-207.

Scott R, Hodge, R., Paul, D. and Draper, J. (1991) The molecular biology of anther differentiation. Plant Science 80, 167-191. 
Shaw MM, Riederer BM (2003) Sample preparation for two-dimensional gel electrophoresis. Proteomics 3, 1408-1417.

Shen S, Matsubae M, Takao T, Tanaka N, Komatsu S (2002) A proteomic analysis of leaf sheaths from rice. $J$ Biochem (Tokyo) 132, 613-620.

Shen S, Sharma A, Komatsu S (2003) Characterization of Proteins Responsive to Gibberellin in the Leaf- Sheath of Rice (Oryza sativa L.) Seedling Using Proteome Analysis. Biol Pharm Bull 26, 129-136.

Shevchenko A, Sunyaev S, Loboda A, Bork P, Ens W, Standing KG (2001) Charting the proteomes of organisms with unsequenced genomes by MALDIquadrupole time-of-flight mass spectrometry and BLAST homology searching. Anal Chem 73, 1917-1926.

Shevchenko A, Wilm M, Vorm O, Mann M (1996) Mass spectrometric sequencing of proteins silver-stained polyacrylamide gels. Anal Chem 68, 850-858.

Sidoli A, Tamborini E, Giuntini I, Levi S, Volonte G, Paini C, De Lalla C, Siccardi AG, Baralle FE, Galliani S, et al. (1993) Cloning, expression, and immunological characterization of recombinant Lolium perenne allergen Lol $\mathrm{p}$ II. J Biol Chem 268, 21819-21825.

Simoens CR, Peleman J, Valvekens D, Van Montagu M, Inze D (1988) Isolation of genes expressed in specific tissues of Arabidopsis thaliana by differential screening of a genomic library. Gene 67, 1-11.

Singh M, Bhalla PL, Xu H, Singh MB (2003) Isolation and characterization of a flowering plant male gametic cell-specific promoter. FEBS Lett 542, 47-52.

Singh MB, Oneill PM, Knox RB (1985) Initiation of Postmeiotic Beta-Galactosidase Synthesis During Microsporogenesis in Oilseed Rape. Plant Physiology 77, 225228.

Skylas DJ, Mackintosh JA, Cordwell SJ, Basseal DJ, Walsh BJ, Harry J, Blumenthal C, Copeland L, Wrigley CW, Rathmell W (2000) Proteome approach to the characterisation of protein composition in the developing and mature wheat-grain endosperm. Journal of Cereal Science 32, 169-188.

Smith AG, Gasser CS, Budelier KA, Fraley RT (1990) Identification and characterization of stamen- and tapetum-specific genes from tomato. Mol Gen Genet 222, 9-16.

Smith DL, Gross KC (2000) A family of at least seven beta-galactosidase genes is expressed during tomato fruit development. Plant Physiol 123, 1173-1183.

Smith PM, Avjioglu A, Ward LR, Simpson RJ, Knox RB, Singh MB (1994a) Isolation and characterization of group-I isoallergens from Bermuda grass pollen. Int Arch Allergy Immunol 104, 57-64. 
Smith PM, Ong EK, Knox RB, Singh MB (1994b) Immunological relationships among group I and group V allergens from grass pollen. Mol Immunol 31, 491498.

Stinson JR, Eissenberg AJ, Willing RP, Pe M, E., Hanson DD, Mascarenhas JP (1987) Genes expressed in the male gametophyte flowering plants and their isolation. Plant Physiol 83, 442-447.

Sturm A (1999) Invertases. Primary structures, functions, and roles in plant development and sucrose partitioning. Plant Physiology 121, 1-7.

Suphioglu C (2000) What are the important allergens in grass pollen that are linked to human allergic disease? Clin Exp Allergy 30, 1335-1341.

Tebbutt SJ, Rogers HJ, Lonsdale DM (1994) Characterization of a tobacco gene encoding a pollen-specific polygalacturonase. Plant Mol Biol 25, 283-297.

Thangavelu M, Belostotsky D, Bevan MW, Flavell RB, Rogers HJ, Lonsdale DM (1993) Partial characterization of the Nicotiana tabacum actin gene family: evidence for pollen-specific expression of one of the gene family members. Mol Gen Genet 240, 290-295.

Theerakulpisut P, Xu H, Singh MB, Pettitt JM, Knox RB (1991) Isolation and developmental expression of Bcp1, an anther-specific cDNA clone in Brassica campestris. Plant Cell 3, 1073-1084.

Theunis CH, Pierson ES, Cresti M (1991) Isolation of Male and Female Gametes in Higher-Plants. Sexual Plant Reproduction 4, 145-154.

Thiellement H, Bahrman N, Damerval C, Plomion C, Rossignol M, Santoni V, de Vienne D, Zivy M (1999) Proteomics for genetic and physiological studies in plants. Electrophoresis 20, 2013-2026.

Thompson JD, Gibson TJ, Plewniak F, Jeanmougin F, Higgins DG (1997) The CLUSTAL_X windows interface: flexible strategies for multiple sequence alignment aided by quality analysis tools. Nucleic Acids Res 25, 4876-4882.

Ticha M, Pacakova V, Stulik K (2002) Proteomics of allergens. J Chromatogr B Analyt Technol Biomed Life Sci 771, 343- 353.

Toriyama K, Hanaoka K, Okada T, Watanabe M (1998) Molecular cloning of a cdna encoding a pollen extracellular protein as a potential source of a pollen allergen in brassica rapa. FEBS Letters 424, 234-238.

Towbin H, Staehelin T, Gordon J (1992) Electrophoretic transfer of proteins from polyacrylamide gels to nitrocellulose sheets: procedure and some applications. 1979. Biotechnology 24, 145-149. 
Treacy BK, Hattori J, Prud'homme I, Barbour E, Boutilier K, Baszczynski CL, Huang B, Johnson DA, Miki BL (1997) Bnm1, a Brassica pollen-specific gene. Plant Mol Biol 34, 603-611.

Triantafillidou D, Georgatsos JG (2001) Barley beta-galactosidase: structure, function, heterogeneity, and gene origin. J Protein Chem 20, 551-562.

Tsai YT, Chen SH, Lin KL, Hsieh KH (1990) Rice pollen allergy in Taiwan. Ann Allergy 65, 459-462.

Tsuchiya T, Toriyama K, Ejiri S, Hinata K (1994) Molecular characterization of rice genes specifically expressed in the anther tapetum. Plant Mol Biol 26, 17371746.

Tsuchiya T, Toriyama K, Nasrallah ME, Ejiri S (1992) Isolation of genes abundantly expressed in rice anthers at the microspore stage. Plant Mol Biol 20, 1189-1193.

Tsugita A, Kamo M, Kawakami T, Ohki Y (1996) Two-dimensional electrophoresis of plant proteins and standardization of gel patterns. Electrophoresis 17, 855865.

Tsugita A, Kawakami T, Uchiyama Y, Kamo M, Miyatake N, Nozu Y (1994) Separation and characterization of rice proteins. Electrophoresis 15, 708-720.

Turcich MP, Hamilton DA, Mascarenhas JP (1993) Isolation and characterization of pollen-specific maize genes with sequence homology to ragweed allergens and pectate lyases. Plant Mol Biol 23, 1061-1065.

Twell D (1994) The diversity and regulation of gene expression in th epathway of male gametophyte development. In 'Molecular and cellular aspects of plant reproduction'. (Eds RJ Scott and AD Stead). (Cambridge University Press)

Twell D, Wing R, Yamaguchi J, McCormick S (1989) Isolation and expression of an anther-specific gene from tomato. Mol Gen Genet 217, 240-245.

Tyers M, Mann M (2003) From genomics to proteomics. Nature 422, 193-197.

Unlu M, Morgan ME, Minden JS (1997) Difference gel electrophoresis: a single gel method for detecting changes in protein extracts. Electrophoresis 18, 20712077.

Ursin VM, Yamaguchi J, McCormick S (1989) Gametophytic and sporophytic expression of anther-specific genes in developing tomato anthers. Plant Cell 1, 727-736.

van Wijk KJ (2001) Challenges and prospects of plant proteomics. Plant Physiol 126, 501-508. 
Vergne P, Delvallee I, Dumas C (1987) Rapid assessment of microspore and pollen development stage in wheat and maize using DAPI and membrane permeabilization. Stain Technol 62, 299-304.

Vidali L, Hepler PK (1997) Characterization and localization of profilin in pollen grains and tubes of Lilium longiflorum. Cell Motil Cytoskeleton 36, 323-338.

Vidali L, Hepler PK (2001) Actin and pollen tube growth. Protoplasma 215, 64-76.

Vierstra RD (2003) The ubiquitin/26S proteasome pathway, the complex last chapter in the life of many plant proteins. Trends Plant Sci 8, 135-142.

Vihinen M (2001) Bioinformatics in proteomics. Biomol Eng 18, 241-248.

Wallin E, von Heijne G (1998) Genome-wide analysis of integral membrane proteins from eubacterial, archaean, and eukaryotic organisms. Protein Sci 7, 1029-1038.

Wang CS, Walling LL, Eckard KJ, Lord EM (1992a) Immunological Characterization of a Tapetal Protein in Developing Anthers of LiliumLongiflorum. Plant Physiology 99, 822-829.

Wang CS, Walling LL, Eckard KJ, Lord EM (1992b) Patterns of Protein Accumulation in Developing Anthers of Lilium-Longiflorum Correlate with Histological Events. American Journal of Botany 79, 118-127.

Wang CS, Walling LL, Eckard KJ, Lord EM (1993) Characterization of an antherspecific glycoprotein in lilium-longiflorum. American Journal of Botany 80, $1155-1161$.

Wasinger VC, Cordwell SJ, Cerpapoljak A, Yan JX, Gooley AA, Wilkins MR, Duncan MW, Harris R, Williams KL, Humpherysmith I (1995) Progress with gene-product mapping of the mollicutes - mycoplasma genitalium. Electrophoresis 16, 1090-1094.

Wasinger VC, Corthals GL (2002) Proteomic tools for biomedicine. J Chromatogr B Analyt Technol Biomed Life Sci 771, 33-48.

Wasinger VC, Pollack JD, Humphery-Smith I (2000) The proteome of Mycoplasma genitalium. Chaps-soluble component. Eur J Biochem 267, 1571-1582.

Wilkins MR, Pasquali C, Appel RD, Ou K, Golaz O, Sanchez JC, Yan JX, Gooley AA, Hughes G, Humphery-Smith I, Williams KL, Hochstrasser DF (1996a) From proteins to proteomes: large scale protein identification by twodimensional electrophoresis and amino acid analysis. Biotechnology (N Y) 14, $61-65$.

Wilkins MR, Sanchez JC, Gooley AA, Appel RD, Humphery-Smith I, Hochstrasser DF, Williams KL (1996b) Progress with proteome projects: why all proteins expressed by a genome should be identified and how to do it. Biotechnol Genet Eng Rev 13, 19-50. 
Willing RP, Bashe D, Mascarenhas JP (1988) An Analysis of the Quantity and Diversity of Messenger-Rnas from Pollen and Shoots of Zea-Mays. Theoretical and Applied Genetics 75, 751-753.

Willing RP, Mascarenhas JP (1984) Analysis of the Complexity and Diversity of Messenger-Rnas from Pollen and Shoots of Tradescantia. Plant Physiology 75, 865-868.

Wilm M, Mann M (1996) Analytical properties of the nanoelectrospray ion source. Anal Chem 68, 1-8.

Wolters DA, Washburn MP, Yates JR, 3rd (2001) An automated multidimensional protein identification technology for shotgun proteomics. Anal Chem 73, 56835690.

Wolters-Arts M, Lush WM, Mariani C (1998) Lipids are required for directional pollen-tube growth. Nature 392, 818-821.

Wuthrich B (1989) Epidemiology of the allergic diseases: are they really on the increase? Int Arch Allergy Appl Immunol 90, 3-10.

Xu H, Swoboda I, Bhalla PL, Singh MB (1999a) Male gametic cell-specific expression of H2A and H3 histone genes. Plant Mol Biol 39, 607-614.

Xu H, Swoboda I, Bhalla PL, Singh MB (1999b) Male gametic cell-specific gene expression in flowering plants. Proc Natl Acad Sci U S A 96, 2554-2558.

Xu H, Theerakulpisut P, Goulding N, Suphioglu C, Singh MB, Bhalla PL (1995a) Cloning, expression and immunological characterization of Ory s 1 , the major allergen of rice pollen. Gene 164, 255-259.

Xu H, Theerakulpisut P, Taylor PE, Knox RB, Singh MB, Bhalla PL (1995b) Isolation of a gene preferentially expressed in mature anthers of rice (oryza sativa 1.). Protoplasma 187, 127-131.

Xu HL, Goulding N, Zhang Y, Swoboda I, Singh MB, Bhalla PL (1999) Promoter region of Ory s 1, the major rice pollen allergen gene. Sexual Plant Reproduction 12, 125-126.

Yanagida M (2002) Functional proteomics; current achievements. J Chromatogr B Analyt Technol Biomed Life Sci 771, 89-106.

Yang WC, Sundaresan V (2000) Genetics of gametophyte biogenesis in Arabidopsis. Curr Opin Plant Biol 3, 53-57.

Yates JR, 3rd (1998) Mass spectrometry and the age of the proteome. J Mass Spectrom 33, $1-19$. 
Yates JR, 3rd (2000) Mass spectrometry. From genomics to proteomics. Trends Genet 16, 5-8.

Yates JR, 3rd, Eng JK, McCormack AL (1995) Mining genomes: correlating tandem mass spectra of modified and unmodified peptides to sequences in nucleotide databases. Anal Chem 67, 3202-3210.

Yee A, Pardee K, Christendat D, Savchenko A, Edwards AM, Arrowsmith CH (2003) Structural proteomics: toward high-throughput structural biology as a tool in functional genomics. Acc Chem Res 36, 183-189.

Ylstra B, Garrido D, Busscher J, Vantunen AJ (1998) Hexose transport in growing petunia pollen tubes and characterization of a pollen-specific, putative monosaccharide transporter. Plant Physiology 118, 297-304.

Yu J, Hu S, Wang J, Wong GK, Li S, Liu B, Deng Y, Dai L, Zhou Y, Zhang X, Cao M, Liu J, Sun J, Tang J, Chen Y, Huang X, Lin W, Ye C, Tong W, Cong L, Geng J, Han Y, Li L, Li W, Hu G, Li J, Liu Z, Qi Q, Li T, Wang X, Lu H, Wu T, Zhu M, Ni P, Han H, Dong W, Ren X, Feng X, Cui P, Li X, Wang H, Xu X, Zhai W, Xu Z, Zhang J, He S, Xu J, Zhang K, Zheng X, Dong J, Zeng W, Tao L, Ye J, Tan J, Chen X, He J, Liu D, Tian W, Tian C, Xia H, Bao Q, Li G, Gao H, Cao T, Zhao W, Li P, Chen W, Zhang Y, Hu J, Liu S, Yang J, Zhang G, Xiong Y, Li Z, Mao L, Zhou C, Zhu Z, Chen R, Hao B, Zheng W, Chen S, Guo W, Tao M, Zhu L, Yuan L, Yang H (2002) A draft sequence of the rice genome (Oryza sativa L. ssp. indica). Science 296, 79-92.

Zapata FJ, Khush GS, Crill JP, Neu MH, Romero RO, Torrizo LB, Alejar M (1983) Rice anther culture at IRRI. In 'Cell and tissue culture techniques for cereal crop improvement' pp. 27-146. (Science Press: Beijing)

Zhang W, Chait BT (2000) ProFound: an expert system for protein identification using mass spectrometric peptide mapping information. Anal Chem 72, 2482-2489.

Zheng HH, Qu LJ, Liu MH, Zhang Y, Shen YP, Wei JM, Pan NS, Gu HY, Chen ZL (2000) An anther-specific chalcone synthase-like gene D5 related to rice pollen development. Chinese Science Bulletin 45, 1921-1926.

Zhong BX, Karibe H, Komatsu S, Ichimura H, Nagamura Y, Sasaki T, Hirano H (1997) Screening of rice genes from a cdna catalog based on the sequence datafile of proteins separated by two-dimensional electrophoresis. Breeding Science 47, 245-251.

Zivy M, de Vienne D (2000) Proteomics: a link between genomics, genetics and physiology. Plant Mol Biol 44, 575-580.

Zou JT, Zhan XY, Wu HM, Wang H, Cheung AY (1994) Characterization of a rice pollen-specific gene and its expression. American Journal of Botany 81, 552561. 


\section{APPENDIX}

\section{Refereed Publications}

1. Kerim, T., Imin, N., Weinman, J. J. and Rolfe, B. G (2003). Proteome analysis reveals developmentally expressed rice homologues of grass group II pollen allergens, Functional Plant biology, 30 (8): 843-852.

2. Kerim, T., Imin, N., Weinman, J. J. and Rolfe, B. G. (2003). Proteome analysis of male gametophyte development in rice anthers, Proteomics 3(5): 738-51.

3. Imin, N., Kerim, T., Weinman, J. J. and Rolfe, B. G. (2001). Characterisation of rice anther proteins expressed at the young microspore stage, Proteomics 1(9): 1149-61.

4. Mathesius, U., Imin, N., Chen, H., Djordjevic, M. A., Weinman, J. J., Natera, S. H., Morris, A. C., Kerim, T., Paul, S., Menzel, C., Weiller, G. F. and Rolfe, B. G. (2002). Evaluation of proteome reference maps for cross-species identification of proteins by peptide mass fingerprinting, Proteomics 2(9): 1288303.

5. Imin N, Kerim T, Weinman JJ, Rolfe BG. Effect of Early Cold Stress on the Maturation of Rice Anthers Proteomics (in press). 


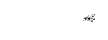

